\title{
Coumarinic Derivatives as Mechanism-Based Inhibitors of $\alpha$-Chymotrypsin and Human Leukocyte Elastase
}

\author{
Lionel Pochet, ${ }^{\mathrm{a}}$ Caroline Doucet, ${ }^{\mathrm{b}}$ Georges Dive, ${ }^{\mathrm{c}}$ Johan Wouters, ${ }^{\mathrm{d}}$ \\ Bernard Masereel, ${ }^{\mathrm{a}, *}$ Michèle Reboud-Ravaux ${ }^{\mathrm{b}}$ and Bernard Pirotte ${ }^{\mathrm{e}}$ \\ a Department of Pharmacy, University of Namur, FUNDP, 61 rue de Bruxelles, B-50000 Namur, Belgium \\ ${ }^{\mathrm{b}}$ Laboratoire d'Enzymologie Moléculaire et Fonctionnelle, Département de Biologie Supramoléculaire et Cellulaire, \\ Institut Jacques Monod, Universités Paris VI et Paris VII, Tour 43, 2, Place Jussieu, F-75251 Paris Cedex 05, France \\ ${ }^{\mathrm{c} C e n t r e ~ d ' i n g e ́ n i e ́ r i e ~ d e s ~ p r o t e ́ i n e s, ~ U n i v e r s i t e ́ ~ d e ~ L i e ̀ g e, ~ a l l e ́ e ~ d e ~ l a ~ C h i m i e ~} 17$ (Bât. B6), B-4000 Liège, Belgium \\ ${ }^{\mathrm{d}}$ Laboratory of Molecular Structures, University of Namur, FUNDP, 61, rue de Bruxelles, B-5000 Namur, Belgium \\ ${ }^{\mathrm{e}}$ Laboratoire de Chimie Pharmaceutique, Université de Liège, 1, av. de l'Hôpital bât B36, tour 4, B-4000 Liège, Belgium
}

Received 13 December 1999; accepted 1 March 2000

\begin{abstract}
Novel coumarinic derivatives were synthesized and tested for their inhibitory potency toward $\alpha$-CT and HLE. Cycloalkyl esters and amides were found to be essentially inactive on both enzymes. On the opposite, aromatic esters strongly inactivated $\alpha$-CT whereas HLE was less efficiently inhibited with dichlorophenyl ester derivatives $\left(k_{\text {inact }} / K_{\mathrm{I}}=4000 \mathrm{M}^{-1} \mathrm{~s}^{-1}\right.$ for 36). Representative examples of amide, ester, thioester and ketone derivatives were prepared in order to evaluate the influence of the link between the coumarinic ring and the phenyl side chain. The irreversible inactivation of $\alpha$-CT by 6 -chloromethyl derivatives should be due to alkylation of a histidine residue as suggested by the amino acid analysis of the modified chymotrypsin. Conversely the inhibition of HLE was transient. Intrinsic reactivity of coumarins has been calculated using a model of a nucleophilic reaction between the ligand and the couple methanol-water. From this calculation, it appears that differences in the inhibitory potency expressed by these molecules cannot only be explained by differences in the reactivity of the lactonic carbonyl group toward the nucleophilic attack. (C) 2000 Elsevier Science Ltd. All rights reserved.
\end{abstract}

\section{Introduction}

Serine proteases are attractive targets for the design of enzyme inhibitors since they are involved in the etiology of several diseases. ${ }^{1-3}$ Within the class of serine proteases, bovine $\alpha$-chymotrypsin $(\alpha-\mathrm{CT})$ constitutes an interesting biological tool for the evaluation of new synthetic inhibitors and may be helpful for the design of new therapeutical tools directed against chymotrypsinlike proteases such as cathepsin $G$ and mast cell chymases. Cathepsin $G$ is implicated in inflammation and mast cell chymases in allergic responses and psoriasis. ${ }^{1}$ Human leukocyte elastase (HLE) is potentially one of the most harmful enzymes in the body. HLE hydrolyzes a wide variety of proteins, including the structural fibronectin, collagen and elastin. ${ }^{2}$ Under physiological conditions, the destructive effects of HLE are limited to the microenvironment immediately surrounding the neutrophils by endogenous proteinase inhibitors

*Corresponding author. Tel.: + 32-81-72-43-38; fax: + 32-81-72-43-38; e-mail: bernard.masereel@fundp.ac.be $(\alpha-1$-proteinase inhibitor, secretory-leukoproteinase inhibitor, elafin). The imbalance between proteases and antiproteases leads to uncontrolled tissue destruction by HLE, which is implicated in the promotion or the exacerbation of a number of diseases including acute respiratory distress syndrome, rheumatoid arthritis, atherosclerosis, pulmonary emphysema and cystic fibrosis. ${ }^{4-8}$

A number of low molecular weight inhibitors of chymotrypsin and elastase-like proteinases have been reported as mechanism-based inhibitors. These include halo enol lactones, ${ }^{9-11} \beta$-lactams, ${ }^{12-16}$ saccharin derivatives, ${ }^{17,18}$ benzoxazinones, ${ }^{19,20}$ substituted isocoumarins, ${ }^{21-23}$ halomethyldihydrocoumarins ${ }^{24,25}$ and thiadiazolidinones. ${ }^{26,27}$

We previously described the development of coumarinic derivatives ${ }^{28}$ characterized by an alkyl, aryl ester (1) or amide (2) function in the position 3 (Fig. 1). The electrophilic chloromethyl moiety in the position 6 was required to irreversibly inhibit $\alpha$-CT. This is consistent with a mechanism in which the lactone group undergoes 
<smiles>CCCC(=O)c1cc2cc(CCl)ccc2oc1=O</smiles>

1<smiles>O=C(S)c1cc2cc(CCl)ccc2oc1=O</smiles>

3<smiles>[R]NC(=O)c1cc2cc(CCl)ccc2oc1=O</smiles><smiles>[R]C(=O)c1cc2cc(CCl)ccc2oc1=O</smiles>

4

Figure 1. Chemical structures of 6-chloromethylcoumarin esters (1), amides (2), thioesters (3) and ketones (4).

the nucleophilic attack of the active serine residue (Fig. 2). After the ring opening, the elimination of HX from the benzylic derivative is a fast reaction in mild conditions when $\mathrm{X}$ is a good leaving group such as a chlorine. ${ }^{29}$ The resulting electrophilic quinone methide could form a covalent bond with a nucleophilic residue such as His-57 or Met-192 located within the enzyme recognition site. Structure-activity relationships established that the nature of the substituent in position 3 strongly influences the inhibitory potency on the serine protease.

According to these considerations, we modulated the coumarinic template in order to improve the inhibitory potency. In the present work, we report the synthesis and the inhibition studies of new cycloalkyl or aryl esters and amides of 6-chloromethyl-2-oxo- $2 \mathrm{H}$-1-benzopyran-3-carboxylic acid. The nature of the substitution on the phenyl side chain was also studied as well as its link to the coumarinic ring. Finally, the interest of the 6-chloromethyl moiety was further investigated. Intrinsic reactivity has been calculated using a model of<smiles>[X]Cc1ccc2oc(=O)c([R])cc2c1</smiles>

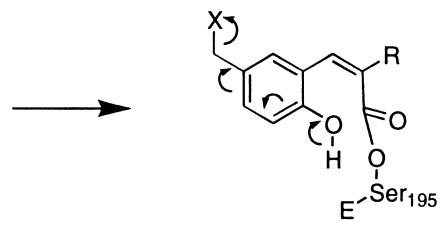

Acyl-enzyme
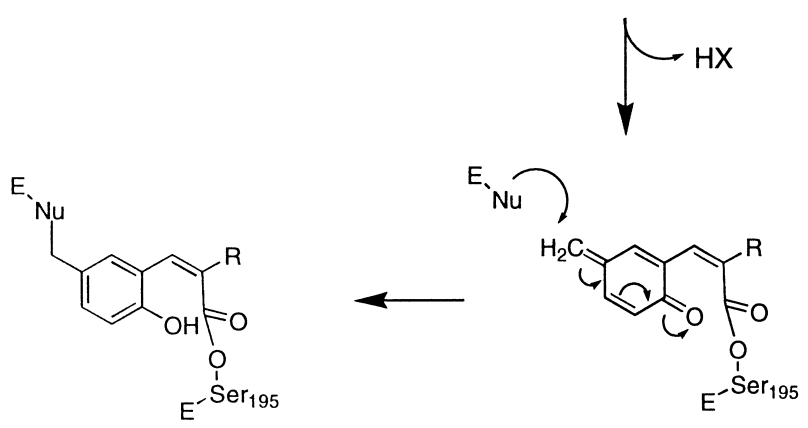

Inactivated enzyme

Figure 2. Postulated mechanism for the inactivation of $\alpha$-chymotrypsin by coumarinic derivatives.

a nucleophilic reaction between the ligand and the couple methanol-water. ${ }^{30}$ The postulated mechanism involves an alkylation within the active site; we performed an amino acid analysis of the modified $\alpha$-CT in order to determine which amino acid residue was alkylated.

\section{Chemistry}

Generally, the acyl chloride of 6-chloromethyl-2-oxo$2 H$-1-benzopyran-3-carboxylic acid $\mathbf{6}$ was obtained by treatment of the starting compound $\mathbf{5}$ with thionyl chloride (Scheme 1). This intermediate $\mathbf{6}$ was then converted into esters $(\mathbf{1 1}-\mathbf{1 5}, \mathbf{2 6}-\mathbf{3 7})$, amides $(\mathbf{1 6}-\mathbf{2 5}, \mathbf{3 8}, \mathbf{4 0})$ or thioesters $(39,41)$ by reaction with the appropriate alcohol, amine or thiol, respectively.

Compound 10 (Scheme 2) was prepared from 5-(hydroxymethyl)salicylaldehyde (7), which reacted with ethyl benzoylacetate (8) in a Knoevenagel-type reaction leading to 3-benzoyl-6-(hydroxymethyl)-2 $H$-1-benzopyren-2-one (9). Treatment of 9 with thionyl chloride led to 3-benzoyl-6-(chloromethyl)-2H-1-benzopyren-2-one (10).

Products 42-47 were prepared from the appropriate carboxylic acid by treatment with thionyl chloride and then with phenol, or 3-chlorophenol, respectively (Scheme 3).

\section{Results and Discussion}

The newly synthesized compounds were examined on $\alpha$ CT and HLE either by the preincubation method or by the progress curve method (Tables 1-4). These coumarin derivatives were expected to act as irreversible inhibitors of $\alpha-\mathrm{CT}$.

In the cycloalkyl ester series, only $\mathbf{1 1}$ and $\mathbf{1 4}\left(k_{\text {inact }} / K_{\mathrm{I}}\right.$ 470 and $3300 \mathrm{M}^{-1} \mathrm{~s}^{-1}$, respectively) weakly inhibited $\alpha-$ CT (Table 1). The cycloalkyl amide derivatives (16-25) failed to inhibit $\alpha$-CT and HLE. These results confirm the influence on the inactivation process of the nature of the substituent at the C-3 position; the presence of an aromatic moiety strongly improves the inhibition. ${ }^{28}$

Consequently, we focused our works on aryl ester derivatives by analyzing the effect on inhibition of substituent on the aromatic moiety. The compounds $\mathbf{2 6 - 3 4}$ and 36 behaved as time-dependent inhibitors of $\alpha$-CT and HLE, whereas 35 was found to be inactive (Table 2). A strong inactivation was observed with derivatives bearing a single halide or a methoxy group located in the meta position (28-31). The presence of a second substituent on the phenyl ring did not improve the inhibitory activity toward $\alpha$-CT (32-36). However, the inhibitory potency toward HLE was increased with the dichlorophenyl ester derivatives $\mathbf{3 4}$ and 36. Since no spontaneous and hydroxylamine-mediated reactivations of the enzyme were observed, the $\alpha$-CT inhibition encountered with these coumarinic derivatives was considered to be irreversible. This phenomenon can be explained by a second hit mechanism (Fig. 2). After the 


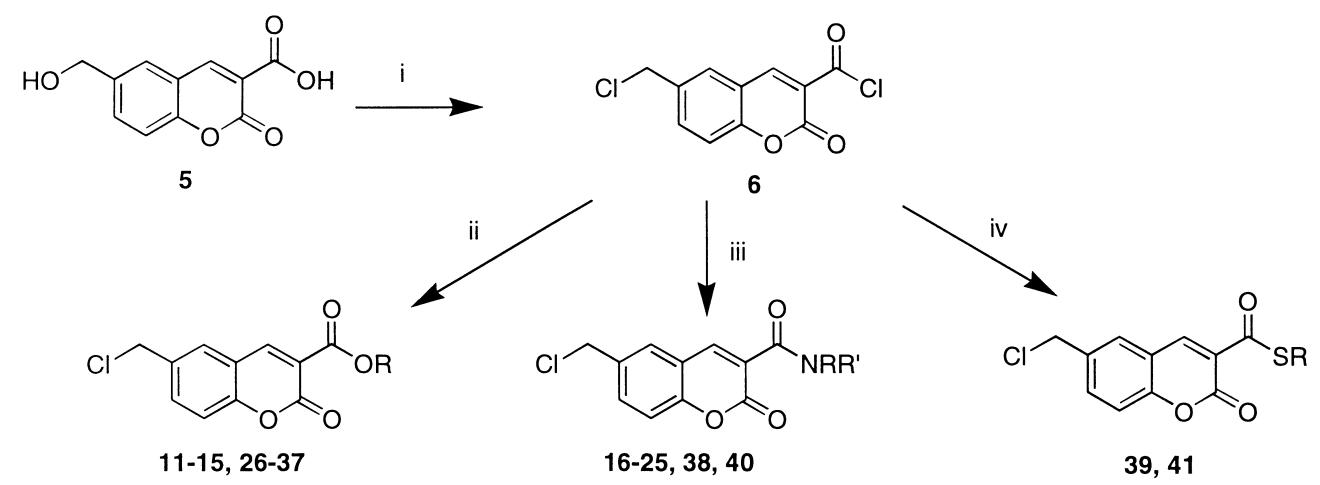

Scheme 1. Reagents: (i) $\mathrm{SOCl}_{2}$; (ii) $\mathrm{ROH} /$ pyridine/dioxane; (iii) $\mathrm{RR}^{\prime} \mathrm{NH} /$ pyridine/dioxane; (iv) $\mathrm{RSH} /$ pyridine/dioxane.<smiles>CCOC(=O)CC(=O)c1ccccc1</smiles>

Scheme 2. Reagents: (i) piperidine/EtOH; (ii) $\mathrm{SOCl}_{2}$.

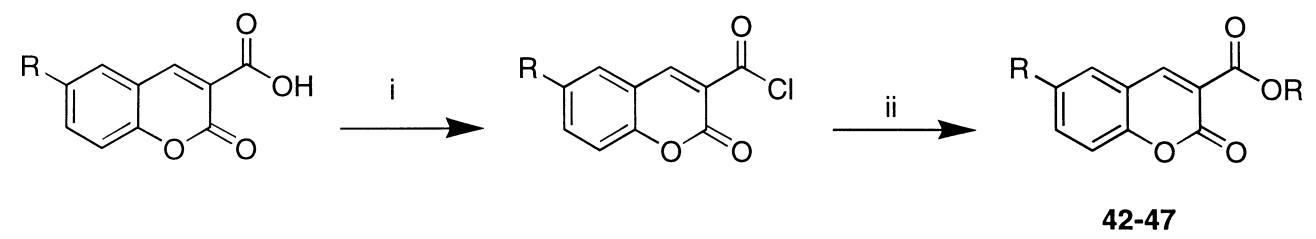

Scheme 3. Reagents: (i) $\mathrm{SOCl}_{2}$; (ii) $\mathrm{ROH} /$ pyridine/dioxane.

nucleophilic attack of the lactonic carbonyl ring and the formation of the acyl enzyme, alkylation of the active site His-57 residue could occur as a consequence of the quinone methide formation resulting from the halogen ion elimination. On the opposite, the inhibition of HLE by coumarin derivatives is transient as evidenced by the slow and complete reactivation within $20 \mathrm{~h}$ of the enzyme treated with compound $\mathbf{3 6}$. This reactivation of the enzyme, speeded up by treatment with hydroxylamine, supports, therefore, the formation of a stable acyl-enzyme, suggesting that these inhibitors act as alternate substrates of HLE. Consequently, the values of $k_{\mathrm{obs}} /[\mathrm{I}]$ reported in Tables $1-4$ correspond to the acylation step.

In order to evaluate the importance of the link between the coumarinic ring and the phenyl residue, we prepared representative examples of amide, ester, thioester and ketone compounds which were tested for their inhibitory potency toward $\alpha-\mathrm{CT}$ and HLE (Fig. 3A and Tables 1-3). As compared to their ester counterparts, the two derivatives with an amide link were found to be inactive (37 versus $\mathbf{3 8}$ and $\mathbf{3 1}$ versus $\mathbf{4 0}$ ). The absence of any inhibitory potency expressed by these amide derivatives could be related to the formation of a strong intramolecular hydrogen bond between the oxygen atom of the lactonic carbonyl and the proton of the amide nitrogen atom. As developed further, this hydrogen bond induces a more restricted conformational mobility of the amide side chain. Interestingly, the inactivation potency of the $m$-chlorophenyl thioester derivative toward $\alpha$-CT was in the same range as that of the corresponding ester ( $\mathbf{3 1}$ versus $\mathbf{4 1}$ ). Replacement of the ester function by a ketone group led to an important decrease of the inhibitory potency ( 37 versus 10).

However, it was interesting to note that $\mathbf{1 0}$ is still an inactivator, in agreement with a reaction of the active serine with the carbonyl group of the lactone. The partition ratio $r$ which represents the average number of enzyme 'turnovers per inactivation' $\left(k_{\mathrm{c}} / k_{\text {inact }}\right)$ was determined for the inhibition of $\alpha$-CT by some of the most powerful inactivators 31, 34, 36 and $\mathbf{4 1}$ and was found equal to 1.8, 2.4, 6.3 and 1.05, respectively (Fig. $3 \mathrm{~B})$. As a result, the partition ratio of thioester $\mathbf{4 1}$ is close to that of an optimal inhibitor (an ideal suicide substrate would display an $r$ value equal to 0 ). 
Table 1. Kinetic parameters for the inactivation of $\alpha-\mathrm{CT}$ ( $\mathrm{pH} 7.5$ and $25^{\circ} \mathrm{C}$ ) and HLE (pH 8.0 and $25^{\circ} \mathrm{C}$ ) by alkyl ester and amide derivatives $^{\mathrm{a}}$<smiles>[Z]C(=O)c1cc2cc(CCl)ccc2oc1=O</smiles>

\begin{tabular}{|c|c|c|c|}
\hline Compound no. & Z & $\begin{array}{c}\alpha-\mathrm{CT} k_{\mathrm{obs}} /[\mathrm{I}] \\
\left(\mathrm{M}^{-1} \mathrm{~s}^{-1}\right)\end{array}$ & $\begin{array}{c}\operatorname{HLE} k_{\mathrm{obs}} /[\mathrm{I}] \\
\left(\mathrm{M}^{-1} \mathrm{~s}^{-1}\right)\end{array}$ \\
\hline 11 & $\mathrm{O}-\mathrm{C}_{6} \mathrm{H}_{11}$ & 470 & ni \\
\hline 12 & $\mathrm{O}-\mathrm{C}_{7} \mathrm{H}_{13}$ & $\mathrm{ni}^{\mathrm{b}}$ & ni \\
\hline 13 & $\mathrm{O}-\mathrm{C}_{8} \mathrm{H}_{15}$ & ni & ni \\
\hline 14 & $\mathrm{O}-\mathrm{C}_{12} \mathrm{H}_{23}$ & 3300 & $\mathrm{ni}$ \\
\hline 15 & O-1-Methyl-piperid-3-yl & 45 & ni \\
\hline 16 & $\mathrm{NH}-\mathrm{C}_{3} \mathrm{H}_{5}$ & $\mathrm{ni}$ & ni \\
\hline 17 & $\mathrm{NH}-\mathrm{C}_{5} \mathrm{H}_{9}$ & $\mathrm{ni}$ & ni \\
\hline 18 & $\mathrm{NH}-\mathrm{C}_{6} \mathrm{H}_{11}$ & $\mathrm{ni}$ & $\mathrm{ni}$ \\
\hline 19 & $\mathrm{NH}-\mathrm{C}_{7} \mathrm{H}_{13}$ & ni & ni \\
\hline 20 & $\mathrm{NH}-\mathrm{C}_{8} \mathrm{H}_{15}$ & ni & $\mathrm{ni}$ \\
\hline 21 & $\mathrm{NH}-\mathrm{C}_{12} \mathrm{H}_{23}$ & ni & $\mathrm{ni}$ \\
\hline 22 & NH-Piperid-1-yl & ni & ni \\
\hline 23 & $\mathrm{~N}\left(\mathrm{C}_{3} \mathrm{H}_{7}\right)_{2}$ & $\mathrm{ni}$ & $\mathrm{ni}$ \\
\hline 24 & 1-Piperidinyl & $\mathrm{ni}$ & $\mathrm{ni}$ \\
\hline 25 & 4-Morpholinyl & ni & ni \\
\hline
\end{tabular}

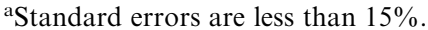

${ }^{\mathrm{b}}$ No inactivation at $10 \mu \mathrm{M}$.

Table 2. Kinetic parameters for the inactivation of $\alpha-\mathrm{CT}(\mathrm{pH} 7.5$ and $25^{\circ} \mathrm{C}$ ) and $\mathrm{HLE}\left(\mathrm{pH} 8.0\right.$ and $25^{\circ} \mathrm{C}$ ) by aryl ester derivatives ${ }^{\mathrm{a}}$<smiles>O=C(Oc1ccccc1)c1cc2cc(CCl)ccc2oc1=O</smiles>

\begin{tabular}{lccc}
\hline Compound no. & $\mathrm{R}$ & $\begin{array}{c}\alpha-\mathrm{CT} k_{\text {inact }} / K_{\mathrm{I}} \\
\left(\mathrm{M}^{-1} \mathrm{~s}^{-1}\right)\end{array}$ & $\begin{array}{c}\mathrm{HLE} k_{\mathrm{obs}} /[\mathrm{II}] \\
\left(\mathrm{M}^{-1} \mathrm{~s}^{-1}\right)\end{array}$ \\
\hline $\mathbf{2 6}$ & $2^{\prime}-\mathrm{NO}_{2}$ & $10,200^{\mathrm{b}}$ & 1250 \\
$\mathbf{2 7}$ & $3^{\prime}-\mathrm{CF}_{3}$ & $<500^{\mathrm{d}}$ & 330 \\
$\mathbf{2 8}$ & $3^{\prime}-\mathrm{OCH}_{3}$ & $188,500^{\mathrm{b}}$ & 98 \\
$\mathbf{2 9}$ & $3^{\prime}-\mathrm{F}$ & 242,000 & 440 \\
$\mathbf{3 0}$ & $3^{\prime}-\mathrm{Br}$ & 560,000 & 290 \\
$\mathbf{3 1}$ & $3^{\prime}-\mathrm{Cl}$ & 762,700 & 630 \\
$\mathbf{3 2}$ & $3^{\prime}-\mathrm{Cl}-5^{\prime}-\mathrm{OCH} \mathrm{CH}_{3}$ & $1200^{\mathrm{d}}$ & 330 \\
$\mathbf{3 3}$ & $2^{\prime}-\mathrm{Cl}-3^{\prime}-\mathrm{Cl}$ & $1200^{\mathrm{d}}$ & $<200$ \\
$\mathbf{3 4}$ & $2^{\prime}-\mathrm{Cl}-5^{\prime}-\mathrm{Cl}$ & 288,000 & $2700^{\mathrm{b}}$ \\
$\mathbf{3 5}$ & $2^{\prime}-\mathrm{Cl}-6^{\prime}-\mathrm{Cl}$ & ni & $<200$ \\
$\mathbf{3 6}$ & $3^{\prime}-\mathrm{Cl}-5^{\prime}-\mathrm{Cl}$ & 110,000 & 4000 \\
\hline
\end{tabular}

aStandard errors are less than $15 \%$.

${ }^{\mathrm{b}} \mathbf{2 6} / \mathrm{CT}: \quad k_{\text {inact }}=0.052 \mathrm{~s}^{-1} ; \quad K_{\mathrm{I}}=5.1 \mu \mathrm{M} . \quad 28 / \mathrm{CT}: \quad k_{\text {inact }}=0.0245 \mathrm{~s}^{-1}$; $K_{\mathrm{I}}=0.13 \mu \mathrm{M}$. 34/HLE: $k_{\text {inact }}=0.006 \mathrm{~s}^{-1} ; K_{\mathrm{I}}=2.2 \mu \mathrm{M}$.

${ }^{\mathrm{c}}$ Data from ref 28

dObtained as $k_{\mathrm{obs}} /[\mathrm{I}]$ at low inhibitor concentration.

eNo inactivation at $10 \mu \mathrm{M}$.

Phenyl 6-methyl-2-oxo-2H-1-benzopyran-3-carboxylate (42), the non-halogenated analogue of $\mathbf{3 7}$, was found to be inactive on $\alpha-\mathrm{CT}$, indicating that the halomethyl moiety is required to obtain an irreversible inactivation of $\alpha$-CT (Table 4). In order to confirm this result, we prepared esters $43-47$ of 2-oxo-2H-1-benzopyran-3-carboxylic acid substituted in the position 6 with a group devoid of a latent alkylating function or bearing a
Table 3. Kinetic parameters for the inactivation of $\alpha-\mathrm{CT}$ ( $\mathrm{pH} 7.5$ and $25^{\circ} \mathrm{C}$ ) and HLE (pH 8.0 and $25^{\circ} \mathrm{C}$ ) by phenyl ester, phenyl amide, phenyl thioester or phenyl ketone derivatives ${ }^{\mathrm{a}}$<smiles>[R]c1cccc(-[Y]2cc3cc(CCl)ccc3oc2=O)c1</smiles>

\begin{tabular}{lcccc}
\hline Compound no. & $\mathrm{Y}$ & $\mathrm{R}$ & $\begin{array}{c}\alpha-\mathrm{CT} k_{\text {inact }} / K_{\mathrm{I}} \\
\left(\mathrm{M}^{-1} \mathrm{~s}^{-1}\right)\end{array}$ & $\begin{array}{c}\mathrm{HLE} k_{\mathrm{obs}} /[\mathrm{I}] \\
\left(\mathrm{M}^{-1} \mathrm{~s}^{-1}\right)\end{array}$ \\
\hline $\mathbf{3 7}^{\mathrm{b}}$ & $\mathrm{COO}$ & $\mathrm{H}$ & 100,000 & 23 \\
$\mathbf{3 8}^{\mathrm{b}}$ & $\mathrm{CONH}$ & $\mathrm{H}$ & 32 & $\mathrm{ni}^{\mathrm{c}}$ \\
$\mathbf{3 9}$ & $\mathrm{COS}$ & $\mathrm{H}$ & 39,000 & $\mathrm{ni}$ \\
$\mathbf{1 0}$ & $\mathrm{CO}$ & $\mathrm{H}$ & 2430 & $\mathrm{ni}$ \\
$\mathbf{3 1}$ & $\mathrm{COO}$ & $\mathrm{Cl}$ & 762,700 & 630 \\
$\mathbf{4 0}$ & $\mathrm{CONH}$ & $\mathrm{Cl}$ & $\mathrm{ni}$ & $\mathrm{ni}$ \\
$\mathbf{4 1}$ & $\mathrm{COS}$ & $\mathrm{Cl}$ & 730,000 & $<200$ \\
\hline
\end{tabular}

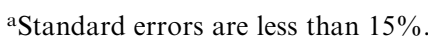

${ }^{b}$ Data from ref 28

${ }^{\mathrm{c}}$ No inactivation at $10 \mu \mathrm{M}$.

Table 4. Kinetic parameters for the inactivation of $\alpha-\mathrm{CT}(\mathrm{pH} 7.5$ and $25^{\circ} \mathrm{C}$ ) and $\mathrm{HLE}\left(\mathrm{pH} 8.0\right.$ and $\left.25^{\circ} \mathrm{C}\right)$ by phenyl or chlorophenyl esters of 6-substituted 2-oxo-2H-1-benzopyran-3-carboxylic acid ${ }^{\mathrm{a}}$<smiles>[R]c1cccc(OC(=O)c2cc3cc([X])ccc3oc2=O)c1</smiles>

\begin{tabular}{lcccc}
\hline $\begin{array}{l}\text { Compound } \\
\text { no. }\end{array}$ & $\mathrm{X}$ & $\mathrm{R}$ & $\begin{array}{c}\alpha-\mathrm{CT} k_{\text {inact }} / K_{\mathrm{I}} \\
\left(\mathrm{M}^{-1} \mathrm{~s}^{-1}\right)\end{array}$ & $\begin{array}{c}\mathrm{HLE} k_{\text {obs }} /[\mathrm{II}] \\
\left(\mathrm{M}^{-1} \mathrm{~s}^{-1}\right)\end{array}$ \\
\hline $\mathbf{4 2}^{\mathrm{b}}$ & $\mathrm{CH}_{3}$ & $\mathrm{H}$ & $\mathrm{ni}$ & 330 \\
$\mathbf{4 3}$ & $\mathrm{H}$ & $\mathrm{H}$ & $\mathrm{ni}$ & 34 \\
$\mathbf{4 4}$ & $\mathrm{CH}_{2} \mathrm{OCOCH}_{3}$ & $\mathrm{H}$ & $\mathrm{ni}$ & $\mathrm{ni}$ \\
$\mathbf{4 5}$ & $\mathrm{CH}_{3}$ & $\mathrm{Cl}$ & 9400 & 1100 \\
$\mathbf{4 6}$ & $\mathrm{H}$ & $\mathrm{Cl}$ & $<500$ & 610 \\
$\mathbf{4 7}$ & $\mathrm{CH}_{2} \mathrm{OCOCH}_{3}$ & $\mathrm{Cl}$ & $20,000^{\mathrm{d}}$ & 1440 \\
\hline
\end{tabular}

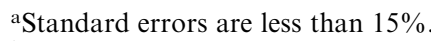

${ }^{b}$ Data from ref 28

cNo inactivation at $10 \mu \mathrm{M}$.

$\mathrm{d} 47 / \mathrm{CT}: k_{\text {inact }}=0.028 \mathrm{~s}^{-1}, K_{\mathrm{I}}=1.4 \mu \mathrm{M}$.

potentially poor leaving group (acetate) (Table 4). Compounds 42 and $\mathbf{4 3}$ did not inactivate $\alpha-C T$ and behaved as substrates $\left(k_{\text {cat }} / K_{\mathrm{m}}=11,600 \mathrm{M}^{-1} \mathrm{~s}^{-1}\right.$ for $\left.\mathbf{4 2}\right)$. Nevertheless, compound 45 inactivated $\alpha$-CT $\left(k_{\text {inact }} /\right.$ $K_{\mathrm{I}}=9400 \mathrm{M}^{-1} \mathrm{~s}^{-1}$ ). This could be explained by the formation of a stable acyl-enzyme (no possibility to unmask an alkylating function). The substitution at the meta position by a chlorine atom strongly influenced the interaction of coumarins with $\alpha$-CT $(\mathbf{4 5} / \mathbf{4 2}, \mathbf{4 6} / \mathbf{4 3}, 47 /$ 44). The inactivation of $\alpha$-CT by 47 was found to be irreversible with a poor partition ratio $(r=80)$. The corresponding 6-chloromethyl analogue $\mathbf{3 1}$ led to a smaller value of $r(r=1.8)$. This may be due to a less nucleofugal leaving group $\left[\mathrm{p} K_{\mathrm{a}}(\right.$ acetate $)=4.76$ and $\left.\mathrm{p} K_{\mathrm{a}}(\mathrm{Cl})=-6.1\right]$. With other series of suicide substrates, it has been reported that acetate, as a leaving group, does not lead to irreversible inhibition. ${ }^{16,31-33}$ In the $\alpha$ CT recognition site, two amino acids may be alkylated: 


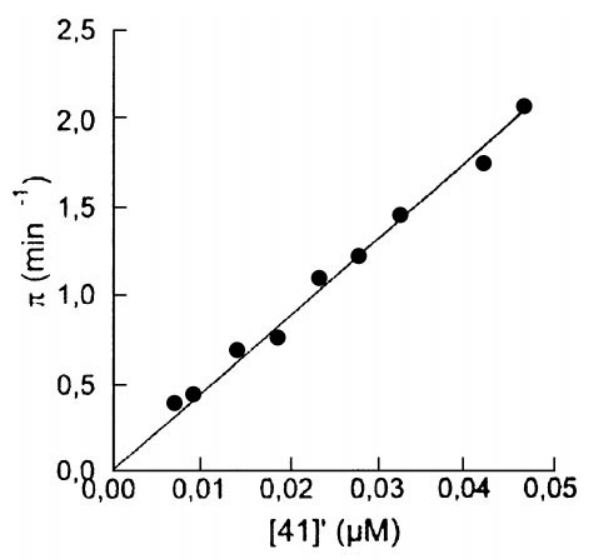

A

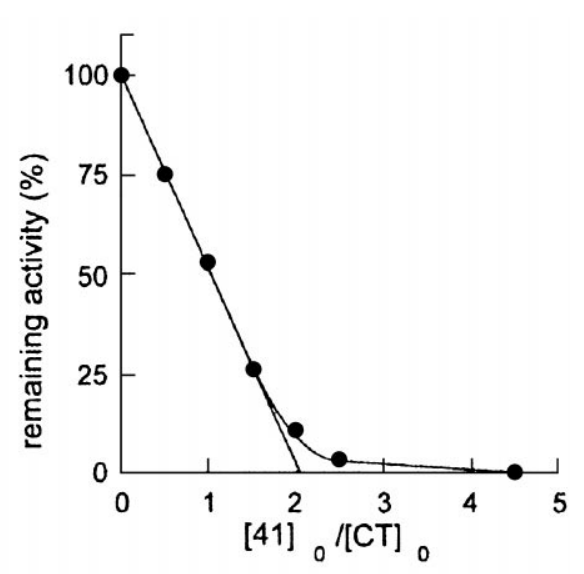

B

Figure 3. Inactivation of $\alpha$-CT by compound 41 at $\mathrm{pH} 7.5$ and $25^{\circ} \mathrm{C}$. A. Determination of the constant $k_{\mathrm{i}} / K_{\mathrm{I}}$ by the progress curve analysis. Plot of $\pi$ versus $[\mathrm{I}]^{\prime}$. B. Determination of the partition ratio. Plot of the remaining activity $(\%)$ at infinite time versus $[\mathrm{I}]_{0} /[\mathrm{E}]_{0}$.

catalytic His-57 or Met-192, which caps the primary specificity pocket. The amino acid analysis of native enzyme and enzyme modified by $\mathbf{3 1}$ and $\mathbf{3 4}$ showed a decrease of the histidine content from 2 residues to 1 with no change in the methionine content. This demonstrates that a histidine residue has been modified and that the inactivation of $\alpha$-CT may be due to the modification of His-57. Interestingly, the 3-chlorophenyl esters 45-47 were found to inhibit HLE with an efficiency equal or superior to that of the 6-chloromethylsubstituted analogue 31. This indicated that the presence of an alkylating group was not required for the inhibition of HLE. This result might be explained by an alternative mode of action. An adequate proximity between the alkylating moiety of the drug and the catalytic histidine should not be realized in the active site of HLE. It should also be speculated that HLE attacks at the exocyclic ester group instead of the lactone. ${ }^{34}$

\section{Optimized geometries of the ligand}

After optimization, 37 revealed two minimal energetic geometries with respect to the dihedral angle $\mathrm{C}_{2}-\mathrm{C}_{3}-\mathrm{C}_{14^{-}}$ $\mathrm{X}_{16}$ value (Table 5). These minima correspond to two conformations ( $\alpha$ and $\beta$ ) characterized by an opposite value for this dihedral angle. The most stable $\beta$-conformation of $\mathbf{3 7}$ is close to that observed in the $\mathrm{X}$-ray structure of 30, where both carbonyl groups point in the same direction (Fig. 4). The energetic level of the transition state structure (TS) between the two conformers is only $3.3 \mathrm{kcal} / \mathrm{mol}$ and it can be assumed that equilibrium between both of them could exist. The same feature occurs for the thioester 39. On the contrary, the amide function in $\mathbf{3 8}$ highly stabilizes the conformer $\alpha$ by an internal $\mathrm{H}$-bond $\left(\mathrm{C}_{2}=\mathrm{O} \cdots \cdot \mathrm{HN}_{16}\right.$, Table 5 and Fig. 5). A first TS is located before the minimum $\beta_{1}$ which itself is separated from a symmetrical other one by a second TS located at $11 \mathrm{kcal} / \mathrm{mol}$ from the first minimum. Thus, it clearly appears that the side chain in the position 3 of the amide $\mathbf{3 8}$ exhibits a lower conformational freedom than that calculated for the corresponding ester $\mathbf{3 7}$ and the thioester 39.
Table 5. Optimized values of the dihedral angle $\phi$ and calculated $\Delta E$ values relative to the $\alpha$ conformation for the ester, the amide and the thioester

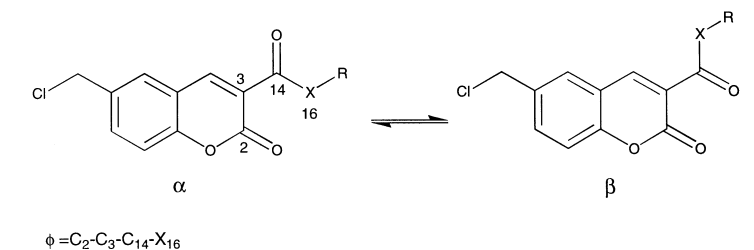

\begin{tabular}{lccc}
\hline Compounds & Conformer & $\phi\left(^{\circ}\right)$ & $\Delta E^{\mathrm{a}}(\mathrm{kcal} / \mathrm{mol})$ \\
\hline Crystal 30 & & -161.2 & \\
$\mathrm{X}_{16}=\mathrm{O}$ & & & \\
$\mathbf{3 7}$ & $\alpha$ & -6.0 & 0.000 \\
$\mathrm{X}_{16}=\mathrm{O}$ & $\mathrm{TS}^{\mathrm{b}}$ & 95.0 & 3.368 \\
& $\beta$ & 181.0 & -0.369 \\
$\mathbf{3 8}$ & $\alpha$ & 0.0 & 0.000 \\
$\mathrm{X}_{16}=\mathrm{NH}$ & $\mathrm{TS}_{1}$ & 96.0 & 9.760 \\
& $\beta_{1}$ & 142.0 & 8.524 \\
& $\mathrm{TS}_{2}$ & 180.0 & 10.818 \\
& $\beta_{2}$ & -142.0 & 8.349 \\
$\mathbf{3 9}$ & $\alpha$ & 4.0 & 0.000 \\
$\mathrm{X}_{16}=\mathrm{S}$ & $\mathrm{TS}$ & 88.0 & 2.945 \\
& $\beta$ & -156.0 & 0.217 \\
\hline
\end{tabular}

aThe energy level of conformer $\alpha$ was set to 0 .

${ }^{\mathrm{b}} \mathrm{TS}$ : transition state.

\section{Nucleophilic model of the intrinsic reactivity}

$\mathrm{Ab}$ initio calculation led us to determine the energetic barrier $(\Delta E)$ required to reach the transition state structure in an interaction model involving the ligand and the couple methanol-water used as nucleophile (Fig. 6 and Table 6). As an example, the two minimum conformations of the amide $\mathbf{3 8}$ and their respective geometry at the transition state are given in Figure 7. This approach has been successfully applied in the study of the acylation mechanism of $\alpha$-chymotrypsin. ${ }^{30}$ The activation barrier for the lactone ring $\mathbf{4 8}$ comprising two conjugated double bonds is significantly higher than that calculated for methyl formate taken as reference. ${ }^{30}$ 


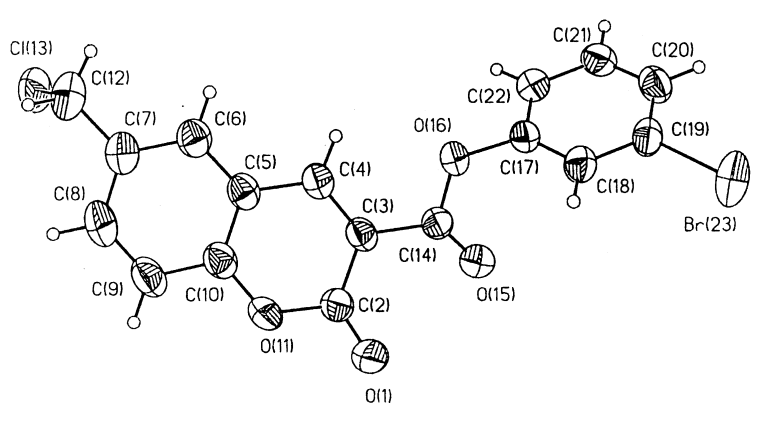

Figure 4. ORTEP representation of X-ray structure of $\mathbf{3 0}$.

By introducing a phenoxycarbonyl moiety in the position 3 of the lactone ring 49 , the $\Delta E$ value is lowered and reflects a higher intrinsic reactivity of the lactonic carbonyl function. This could be explained by the electron withdrawing effect of the phenoxycarbonyl group. Adjunction of a benzene ring to the lactone $\mathbf{4 8}$ leading to coumarin $\mathbf{5 0}$ slightly increases the reactivity. The intrinsic reactivity of the 6-chloromethyl-substituted coumarinic compound $\mathbf{5 1}$ is also improved when compared to the lactone ring alone (48) or the coumarin $\mathbf{5 0 .}$ Association of the coumarinic structure with a phenoxycarbonyl moiety in the position 3 (52) leads to a theoretical intrinsic reactivity slightly lower than that of $\mathbf{3 7}$, which includes a chloromethyl substituent. Thus, a coumarinic compound bearing a 3-phenoxycarbonyl and/or a 6-chloromethyl group may have a higher reactivity compared to the simple coumarinic derivative $\mathbf{5 0}$, devoid of both substituents. These results also confirm that the coumarinic core structure like $\mathbf{3 7}$ should have the appropriate reactivity for interacting with serine enzymes. Further calculations have been made in order to appreciate the influence of the position of the chlor- ine atom on the phenyl ring. As observed in Figure 6, only slight differences are noted between compounds $\mathbf{5 3}$, 31 and 54. Their $\Delta E$ is similar or lower to that of 37, devoid of this halogen atom. Indeed, a slight increase of the intrinsic reactivity is only noted for 53, the ortho chloride derivative. By comparison with compound 53, the energy barrier of the 2,6-dichloro substituted derivative $\mathbf{3 5}$ is slightly increased and that of compound $\mathbf{3 3}$ is decreased. Even though the intrinsic reactivity of all the mono- and di-chloro derivatives remains in the the same energetic range, the inhibitory potency greatly differs. For example, the 2,6-dichloro substituted derivative 35 is inactive against $\alpha$-CT whereas the 2,5dichloro $\mathbf{3 4}$ is very potent (Table 2). Consequently, differences in the inhibitory activity expressed by these chlorophenyl or dichlorophenyl molecules (Table 2 and ref 35) cannot be only explained by differences in the reactivity of the lactonic carbonyl group involved in the nucleophilic attack. The most important geometric feature which could explain the marked variations in the kinetic parameters toward $\alpha$-CT is probably related to the preferential conformation adopted by the substituted phenoxycarbonyl side chain. Finally, the examination of the antiparallel $\alpha$ conformer and parallel $\beta$ conformer of 38 led to the conclusion that the conformation $38 \alpha$ gave a significantly higher reactivity of the lactonic carbonyl compared to the conformation $38 \beta$ (Table 6 and Fig. 7). This phenomenon is directly related to the stabilization of the partially negatively charged $\mathrm{O}$ carbonyl by the neighboring $\mathrm{H}-\mathrm{N}$ amide group (Fig. 7). However, even if the theoretical reactivity of the amide $\mathbf{3 8} \alpha$ was higher than the corresponding ester $\mathbf{3 7}$, the lack of inhibitory activity of $\mathbf{3 8}$ should be explained by the restricted conformational freedom of the amide, which should be responsible for a lowering of the recognition adaptability during receptor site interaction. Regarding compounds $\mathbf{3 7}$ and 39, no differences are noted for the activation energy of $\alpha$ and $\beta$ (Table 6).

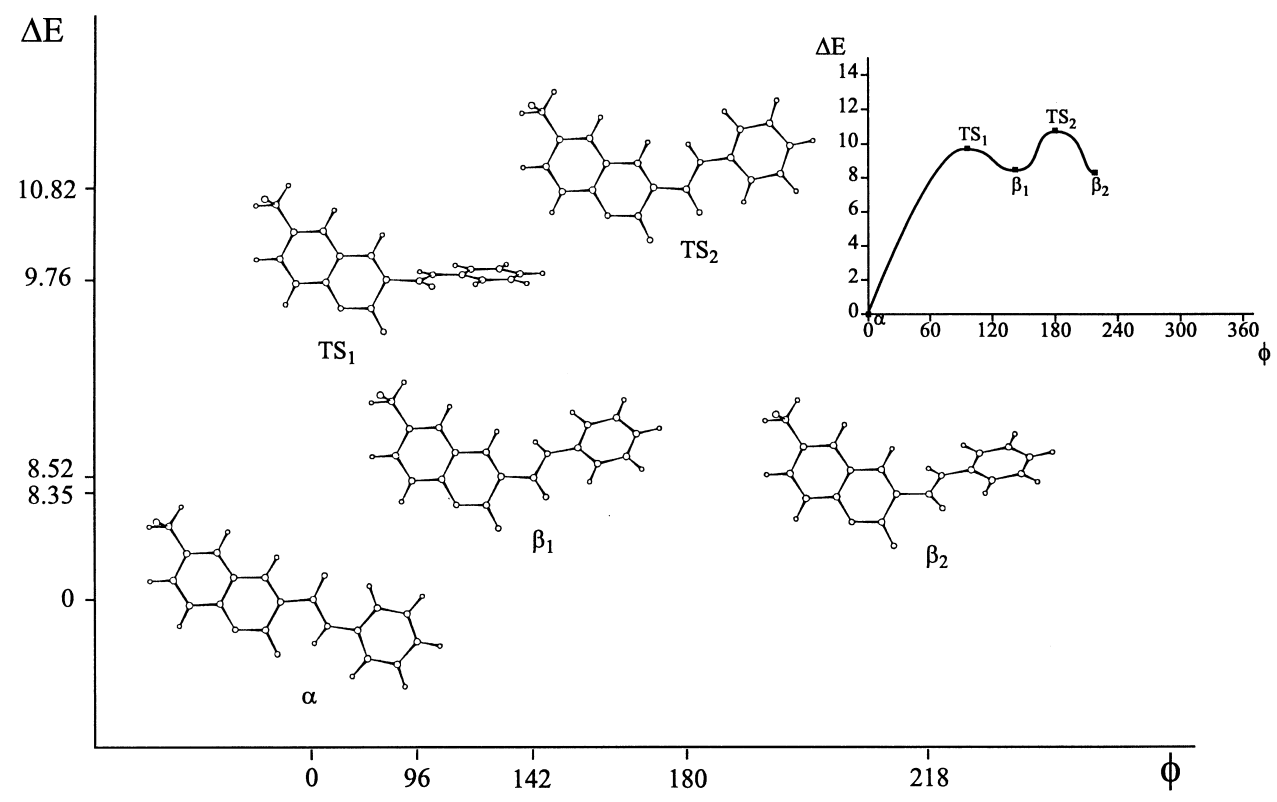

Figure 5. Conformational study of the amide 38 . 


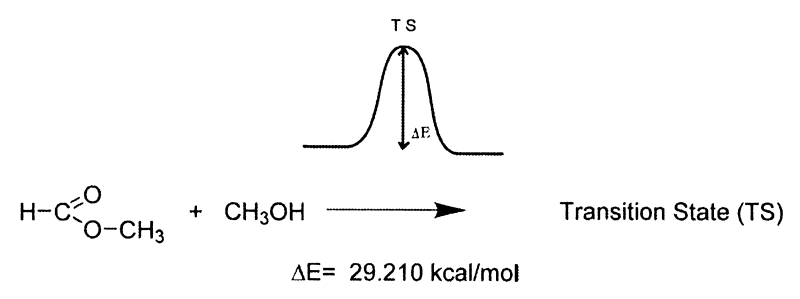<smiles>O=c1cccco1</smiles>
$\Delta E=37.934 \mathrm{kcal} / \mathrm{mol}$<smiles>O=c1ccc2cc(CCl)ccc2o1</smiles>
$\Delta \mathrm{E}=35.497 \mathrm{kcal} / \mathrm{mol}$<smiles>O=C(Oc1ccccc1Cl)c1cc2cc(CCl)ccc2oc1=O</smiles>
$\Delta \mathrm{E}=31.784 \mathrm{kcal} / \mathrm{mol}$<smiles>O=C(Oc1ccccc1)c1cccoc1=O</smiles>

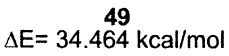<smiles>O=C(Oc1ccccc1)c1cc2ccccc2oc1=O</smiles>
$\Delta E=33.616 \mathrm{kcal} / \mathrm{mol}$<smiles>O=C(Oc1cccc(Cl)c1)c1cc2cc(CCl)ccc2oc1=O</smiles>
$\Delta \mathrm{E}=32.709 \mathrm{kcal} / \mathrm{mol}$<smiles>O=c1ccc2ccccc2o1</smiles>

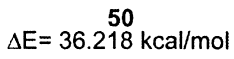<smiles>O=C(Oc1ccccc1)c1cc2cc(CCl)ccc2oc1=O</smiles>

$\Delta E=32.800 \mathrm{kcal} / \mathrm{mol}$<smiles>O=C(Oc1ccc(Cl)cc1)c1cc2cc(CCl)ccc2oc1=O</smiles>

$\Delta E=32.626 \mathrm{kcal} / \mathrm{mol}$<smiles>O=C(Oc1cccc(Cl)c1Cl)c1cc2cc(CCl)ccc2oc1=O</smiles>
$\Delta \mathrm{E}=31.549 \mathrm{kcal} / \mathrm{mol}$<smiles>O=C(Oc1cc(Cl)ccc1Cl)c1cc2cc(CCl)ccc2oc1=O</smiles>
$\Delta E=33.277 \mathrm{kcal} / \mathrm{mol}$<smiles>O=C(Oc1c(Cl)cccc1Cl)c1cc2cc(CCl)ccc2oc1=O</smiles>

$\Delta E=32.677 \mathrm{kcal} / \mathrm{mol}$<smiles>O=C(Oc1cc(Cl)cc(Cl)c1)c1cc2cc(CCl)ccc2oc1=O</smiles>

$\Delta E=32.761 \mathrm{kcal} / \mathrm{mol}$

Figure 6. Intrinsic reactivity of the nucleophilic reaction.

\section{Conclusion}

The ester and thioester coumarinic derivatives possess the structural requirements to act as efficient inactivators of serine proteases. The lack of inhibitory activity of the amide derivatives should be explained by a poor recognition of the molecule by the enzyme rather than by a lack of reactivity toward nucleophilic addition. The determination of intrinsic reactivity of the lactone indicates that the potency of the phenyl derivatives is rather due to the conformation of the phenoxycarbonyl side chain than the intrinsic reactivity of the lactone. In order to support this theoretical approach, the kinetic parameters of alkaline hydrolysis of these coumarins could be helpful. ${ }^{36,37}$ The irreversible inactivation of $\alpha$-CT by these compounds probably implies an alkylation of a histidine residue in the receptor site. On the contrary, the inactivation of HLE was transient and the enzyme slowly recovered its activity. The modulation of substituents in the position 3 and in the position 6 opens the way for the design of selective inhibitors of HLE.

\section{Experimental}

\section{Chemistry}

Melting points were determined with a Büchi-Tottoli apparatus in open capillary tubes and are uncorrected. Analyses (C, H, N) were performed on a Carbo-Erba analyzer and were within $\pm 0.4 \%$ of the theoretical values. The IR spectra were recorded in $\mathrm{KBr}$ on a Perkin-Elmer 1750 spectrophotometer. The ${ }^{1} \mathrm{H}$ NMR spectra were recorded in $\mathrm{CDCl}_{3}$ (or DMSO- $d_{6}$ ) on a Bruker AW $80(80 \mathrm{MHz})$ or a Jeol JNM-EX 400 (400 MHz). TMS was used as an internal standard and chemical shifts are reported in $\delta$ values (ppm) relative to internal TMS. 
Table 6. Activation energy of the nucleophilic reaction

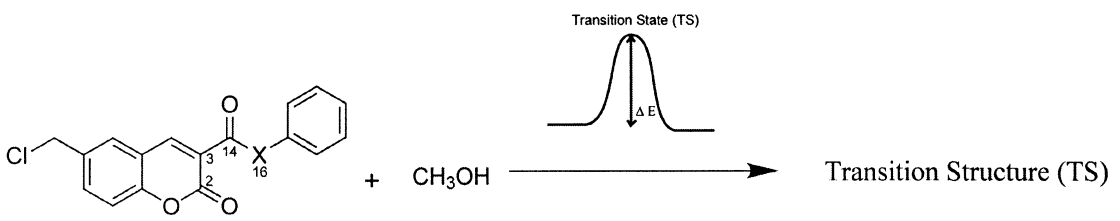

\begin{tabular}{|c|c|c|c|}
\hline Compounds & Conformer & $\phi\left(^{\circ}\right)$ & $\Delta E^{\mathrm{a}}(\mathrm{kcal} / \mathrm{mol})$ \\
\hline $\begin{array}{l}37 \\
X_{16}=O\end{array}$ & $\begin{array}{c}\alpha \\
\mathrm{TS}^{\mathrm{b}} \\
\beta \\
\mathrm{TS}\end{array}$ & $\begin{array}{c}-6.0 \\
-13.0 \\
181.0 \\
168.0\end{array}$ & $\begin{array}{c}0.000 \\
32.800 \\
0.000 \\
32.862\end{array}$ \\
\hline $\begin{array}{l}38 \\
X_{16}=N H\end{array}$ & $\begin{array}{c}\alpha \\
\mathrm{TS} \\
\beta_{1} \\
\mathrm{TS}\end{array}$ & $\begin{array}{c}0.0 \\
14.0 \\
142.0 \\
139.0\end{array}$ & $\begin{array}{c}0.000 \\
29.152 \\
0.000 \\
32.225\end{array}$ \\
\hline $\begin{array}{l}39 \\
X_{16}=S\end{array}$ & $\begin{array}{c}\alpha \\
\text { TS } \\
\beta \\
\text { TS }\end{array}$ & $\begin{array}{c}4.0 \\
5.0 \\
-156.0 \\
155.0\end{array}$ & $\begin{array}{c}0.000 \\
33.376 \\
0.000 \\
32.980\end{array}$ \\
\hline
\end{tabular}

aThe energy level of each minimum conformer was fixed to $0 \mathrm{kcal} / \mathrm{mol}$.

${ }^{\mathrm{b}}$ Transition state.
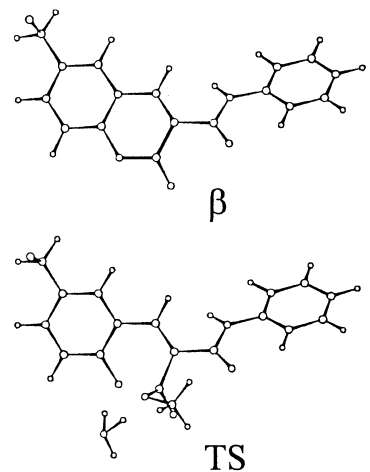

Figure 7. The two minimum conformations of the amide and their respective geometries at the transition state during the reaction with the couple methanol-water.

3-Benzoyl-6-(hydroxymethyl)-2H-1-benzopyren-2-one (9). A mixture of 5-(hydroxymethyl)salicylaldehyde (7) $(0.76 \mathrm{~g}, 5 \mathrm{mmol})$, ethyl benzoylacetate $(\mathbf{8}, 1.056 \mathrm{~g}$, $5.5 \mathrm{mmol})$, piperidine $(0.1 \mathrm{~mL})$ and ethanol $(5 \mathrm{~mL})$ was refluxed for $10 \mathrm{~min}$. After cooling, the precipitate was collected and washed with ethanol to give the title compound (0.63 g, 45\%): $\mathrm{mp} 170-172{ }^{\circ} \mathrm{C}$; IR $3031(\mathrm{C}-\mathrm{H}$ arom), 1712 ( $\mathrm{C}=\mathrm{O}$ lactone), 1671 ( $\mathrm{C}=\mathrm{O}$ ketone), 1624, 1581, $1269 \mathrm{~cm}^{-1} ;{ }^{1} \mathrm{H}$ NMR (400 MHz, $\left.\mathrm{CDCl}_{3}, \mathrm{TMS}\right), \delta$ $4.80\left(\mathrm{~s}, 2 \mathrm{H}, \mathrm{CH}_{2} \mathrm{OH}\right), 7.41(\mathrm{~d}, 1 \mathrm{H}, 8-\mathrm{H}), 7.49(\mathrm{dd}, 2 \mathrm{H}$, $\left.3^{\prime}-\mathrm{H}, 5^{\prime}-\mathrm{H}\right), 7.61-7.65$ (m, 3H, 2'-H, 4'-H, 6'-H), 7.88 (s, 1H, 5-H), 7.89 (d, 1H, 7-H), 8.07 (s, 1H, 4-H). Anal. $\left(\mathrm{C}_{17} \mathrm{H}_{12} \mathrm{O}_{4}\right) \mathrm{C}, \mathrm{H}$.

3-Benzoyl-6-(chloromethyl)-2H-1-benzopyren-2-one (10). 3-Benzoyl-6-(hydroxymethyl)-2H-1-benzopyren-2-one (9) $(1 \mathrm{~g} ; 3.57 \mathrm{mmol})$ was heated in thionyl chloride $(10 \mathrm{~mL})$ for $3 \mathrm{~h}$. The resulting solution was concentrated under reduced pressure and the residue was dispersed in dry toluene $(10 \mathrm{~mL})$. After elimination of the solvent under reduced pressure, the residue of crude $\mathbf{1 0}$ was recrystallized in ethyl actetate:petroleum ether 40$60{ }^{\circ} \mathrm{C}$ to give the title compound $(0.87 \mathrm{~g}, 82 \%)$ : mp 178 $179{ }^{\circ} \mathrm{C}$; IR 3067 (C-H arom), 1712 (C=O lactone), 1662 ( $\mathrm{C}=\mathrm{O}$ ketone), 1624, 1575, $1251 \mathrm{~cm}^{-1} ;{ }^{1} \mathrm{H}$ NMR $\left(400 \mathrm{MHz}, \mathrm{CDCl}_{3}, \mathrm{TMS}\right), \delta 4.66\left(\mathrm{~s}, 2 \mathrm{H}, \mathrm{CH}_{2} \mathrm{Cl}\right), 7.42$ (d, 1H, 8-H), $7.50\left(\mathrm{dd}, 2 \mathrm{H}, 3^{\prime}-\mathrm{H}, 5^{\prime}-\mathrm{H}\right), 7.61-7.69(\mathrm{~m}$, $\left.3 \mathrm{H}, 2^{\prime}-\mathrm{H}, 4^{\prime}-\mathrm{H}, 6^{\prime}-\mathrm{H}\right), 7.88$ (s, 1H, 5-H), 7.89 (d, 1H, 7$\mathrm{H}), 8.07$ (s, 1H, 4-H). Anal. $\left(\mathrm{C}_{17} \mathrm{H}_{11} \mathrm{O}_{3} \mathrm{Cl}\right) \mathrm{C}, \mathrm{H}$.

General procedure for the preparation of the esters (11-15, 31, 37), thioesters $(39,41)$ and amides (16-25, $38,40)$ of 6-chloromethyl-2-oxo-2H-1-benzopyran-3carboxylic acid, of the esters of 2-oxo- $2 \mathrm{H}$-1-benzopyran-3-carboxylic acid $(43,46)$ and of the esters of 6-acetoxymethyl- $(44,47)$ and 6-methyl-2-oxo-2H-1benzopyran-3-carboxylic acids $(42,45)$

The appropriate coumarinic acid ( $1 \mathrm{~g}$ ) was suspended in thionyl chloride $(10 \mathrm{~mL})$ for $3 \mathrm{~h}$. The resulting solution was evaporated to dryness under reduced pressure and the residue was dispersed in dry toluene $(10 \mathrm{~mL})$. The solvent was eliminated under reduced pressure. Dispersion in dry toluene and solvent elimination was repeated twice. The residue reacted with the appropriate alcohol (1.1 equiv), amine (1.1 equiv) or thiol (1.1 equiv) in the presence of anhydrous pyridine as previously described. ${ }^{28}$

Cyclohexyl 6-(chloromethyl)-2-oxo-2H-1-benzopyran-3carboxylate (11). This was prepared according to the general procedure (yield: 47\%): mp 185-186 ${ }^{\circ} \mathrm{C}$ (ethyl acetate); IR 3064 (C-H arom), 2939, 2860 (C-H aliph), $1743(\mathrm{C}=\mathrm{O}$ ester $), 1712(\mathrm{C}=\mathrm{O}$ lactone $), 1628,1580$, 1274, $1256 \mathrm{~cm}^{-1} ;{ }^{1} \mathrm{H}$ NMR $\left(80 \mathrm{MHz}, \mathrm{CDCl}_{3} / \mathrm{DMSO}\right.$, HMDS), $\delta$ 1.25-1.85 (m, 10H, $\left.\left(\mathrm{CH}_{2}\right)_{5}\right), 4.55(\mathrm{~s}, 2 \mathrm{H}$, $\left.\mathrm{CH}_{2} \mathrm{Cl}\right), 5.00(\mathrm{~m}, 1 \mathrm{H}, \mathrm{CH}), 7.30(\mathrm{~d}, 1 \mathrm{H}, 8-\mathrm{H}), 7.55$ (s, 1H, 5-H), 7.60 (d, 1H, 7-H), 8.35 (s, 1H, 4-H). Anal. $\left(\mathrm{C}_{17} \mathrm{H}_{17} \mathrm{O}_{4} \mathrm{Cl}\right) \mathrm{C}, \mathrm{H}$. 
Cycloheptyl 6-(chloromethyl)-2-oxo-2H-1-benzopyran-3carboxylate (12). This was prepared according to the general procedure (yield: $28 \%$ ): $\mathrm{mp} 171-174^{\circ} \mathrm{C}$ (ethyl acetate); IR 3062 (C-H arom), 2932, 2855 (C-H aliph), $1743(\mathrm{C}=\mathrm{O}$ ester), $1708 \quad(\mathrm{C}=\mathrm{O}$ lactone $), 1628,1580$, 1273, $1256 \mathrm{~cm}^{-1} ;{ }^{1} \mathrm{H}$ NMR (80 MHz, CDCl 3 , HMDS), $\delta$ 1.35-1.80 (m, 12H, $\left.\left(\mathrm{CH}_{2}\right)_{6}\right), 4.55\left(\mathrm{~s}, 2 \mathrm{H}, \mathrm{CH}_{2} \mathrm{Cl}\right), 5.55$ (m, 1H, CH), 7.25 (d, 1H, 8-H), 7.50 (s, 1H, 5-H), 7.55 $(\mathrm{d}, 1 \mathrm{H}, 7-\mathrm{H}), 8.35(\mathrm{~s}, 1 \mathrm{H}, 4-\mathrm{H})$. Anal. $\left(\mathrm{C}_{18} \mathrm{H}_{19} \mathrm{O}_{4} \mathrm{Cl}\right)$ C, H.

Cyclooctyl 6-(chloromethyl)-2-oxo-2H-1-benzopyran-3carboxylate (13). This was prepared according to the general procedure (yield: $35 \%$ ): $\mathrm{mp} 169-170^{\circ} \mathrm{C}$ (ethyl acetate:petroleum ether $\left.40-60{ }^{\circ} \mathrm{C}\right)$; IR $3061 \quad(\mathrm{C}-\mathrm{H}$ arom), 2925, 2853 (C-H aliph), 1742 (C=O ester), 1708 (C=O lactone), 1627, 1580, 1274, $1256 \mathrm{~cm}^{-1} ;{ }^{1} \mathrm{H}$ NMR $\left(80 \mathrm{MHz}, \mathrm{CDCl}_{3}, \mathrm{HMDS}\right), \delta 1.40-1.80(\mathrm{~m}, 14 \mathrm{H}$, $\left.\left(\mathrm{CH}_{2}\right)_{7}\right), 4.55\left(\mathrm{~s}, 2 \mathrm{H}, \mathrm{CH}_{2} \mathrm{Cl}\right), 5.10(\mathrm{~m}, 1 \mathrm{H}, \mathrm{CH}), 7.25$ (d, $1 \mathrm{H}, 8-\mathrm{H}), 7.50(\mathrm{~s}, 1 \mathrm{H}, 5-\mathrm{H}), 7.55(\mathrm{~d}, 1 \mathrm{H}, 7-\mathrm{H}), 8.30$ (s, $1 \mathrm{H}, 4-\mathrm{H})$. Anal. $\left(\mathrm{C}_{19} \mathrm{H}_{21} \mathrm{O}_{4} \mathrm{Cl}\right) \mathrm{C}, \mathrm{H}$.

Cyclododecyl 6-(chloromethyl)-2-oxo-2H-1-benzopyran3-carboxylate (14). This was prepared according to the general procedure (yield: $58 \%$ ): $\mathrm{mp} 164-167^{\circ} \mathrm{C}$ (ethyl acetate:petroleum ether $\left.40-60^{\circ} \mathrm{C}\right)$; IR $3051 \quad(\mathrm{C}-\mathrm{H}$ arom), 2928, 2864 (C-H aliph), 1747 (C=O ester), 1699 $(\mathrm{C}=\mathrm{O}$ lactone $), 1623,1578,1475,1304,1272,1255$ $\mathrm{cm}^{-1} ;{ }^{1} \mathrm{H}$ NMR $\left(80 \mathrm{MHz}, \mathrm{CDCl}_{3}, \mathrm{HMDS}\right), \delta 1.10-1.70$ $\left(\mathrm{m}, 22 \mathrm{H},\left(\mathrm{CH}_{2}\right)_{11}\right), 4.55\left(\mathrm{~s}, 2 \mathrm{H}, \mathrm{CH}_{2} \mathrm{Cl}\right), 5.20(\mathrm{~m}, 1 \mathrm{H}$, $\mathrm{CH}), 7.25$ (d, 1H, 8-H), 7.55 (s, 1H, 5-H), 7.60 (d, 1H, 7$\mathrm{H}), 8.35$ (s, $1 \mathrm{H}, 4-\mathrm{H})$. Anal. $\left(\mathrm{C}_{23} \mathrm{H}_{29} \mathrm{O}_{4} \mathrm{Cl}\right) \mathrm{C}, \mathrm{H}$.

1-Methylpiperid-3-yl 6-(chloromethyl)-2-oxo-2H-1-benzopyran-3-carboxylate (15). This was prepared according to the general procedure (yield: $26 \%$ ): $\operatorname{mp~} 217^{\circ} \mathrm{C} \mathrm{dec}$. (ethyl acetate:petroleum ether $\left.40-60^{\circ} \mathrm{C}\right)$; IR $3058(\mathrm{C}-\mathrm{H}$ arom), 2940, 2778 (C-H aliph), 1742 ( $\mathrm{C}=\mathrm{O}$ ester), 1714 (C=O lactone), 1630, 1581, 1273, $1255 \mathrm{~cm}^{-1} ;{ }^{1} \mathrm{H}$ NMR (400 MHz, $\left.\mathrm{CDCl}_{3}, \mathrm{TMS}\right), \delta 1.75\left(\mathrm{~m}, 2 \mathrm{H}, 5^{\prime}-\mathrm{H}\right), 2.32$ (s, $\left.3 \mathrm{H}, \mathrm{CH}_{3},\right)$ 2.45-2.76 (m, 6H, 2'-H, 4'-H, 6'-H), 4.64 (s, $\left.2 \mathrm{H}, \mathrm{CH}_{2} \mathrm{Cl}\right), 5.15-5.17$ (m, 1H, 3'-H), 7.35 (d, 1H, 8-H), 7.65-7.66 (d+s, 2H, 5-H, 7-H), 8.54 (s, 1H, 4-H). Anal. $\left(\mathrm{C}_{17} \mathrm{H}_{18} \mathrm{NO}_{4} \mathrm{Cl}\right) \mathrm{C}, \mathrm{H}, \mathrm{N}$.

\section{N-Cyclopropyl-6-(chloromethyl)-2-oxo-2H-1-benzopyran- 3-carboxamide (16). This was prepared according to the general procedure (yield: 54\%): $\mathrm{mp} 222-225^{\circ} \mathrm{C}$ (ethyl acetate:petroleum ether 40-60 $\left.{ }^{\circ} \mathrm{C}\right)$; IR $3294(\mathrm{~N}-\mathrm{H}), 3046$ (C-H arom), 1728 ( $\mathrm{C}=\mathrm{O}$ lactone), 1651 ( $\mathrm{C}=\mathrm{O}$ amide), 1612, 1574, $1519 \mathrm{~cm}^{-1}$; ${ }^{1} \mathrm{H}$ NMR $\left(400 \mathrm{MHz}, \mathrm{CDCl}_{3}\right.$, TMS), $\delta$ 0.64-0.89 (m, 4H, $\left.\left(\mathrm{CH}_{2}\right)_{2}\right), 2.96-2.97(\mathrm{~m}, 1 \mathrm{H}$, $\mathrm{CH}), 4.66\left(\mathrm{~s}, 2 \mathrm{H}, \mathrm{CH}_{2} \mathrm{Cl}\right), 7.40(\mathrm{~d}, 1 \mathrm{H}, 8-\mathrm{H}), 7.69$ (d, $1 \mathrm{H}, 7-\mathrm{H}), 7.71(\mathrm{~s}, 1 \mathrm{H}, 5-\mathrm{H}), 8.91$ (s, 1H, 4-H). Anal. $\left(\mathrm{C}_{14} \mathrm{H}_{12} \mathrm{NO}_{3} \mathrm{Cl}\right) \mathrm{C}, \mathrm{H}, \mathrm{N}$.}

$\mathrm{N}$-Cyclopentyl-6-(chloromethyl)-2-oxo-2H-1-benzopyran3-carboxamide (17). This was prepared according to the general procedure (yield: $43 \%$ ): $\mathrm{mp} 218-220^{\circ} \mathrm{C}$ (ethyl acetate:petroleum ether $\left.40-60^{\circ} \mathrm{C}\right)$; IR $3321(\mathrm{~N}-\mathrm{H}), 3037$ (C-H arom), 2965, 2864 (C-H aliph), 1729 (C=O lactone), 1649 ( $\mathrm{C}=\mathrm{O}$ amide), 1618, 1580, $1541 \mathrm{~cm}^{-1} ;{ }^{1} \mathrm{H}$ NMR $\left(80 \mathrm{MHz}, \mathrm{CDCl}_{3}, \mathrm{TMS}\right), \delta 1.25-2.10(\mathrm{~m}, 8 \mathrm{H}$,
$\left(\mathrm{CH}_{2}\right)_{4}, 4.40(\mathrm{~m}, 1 \mathrm{H}, \mathrm{CH}), 4.65\left(\mathrm{~s}, 2 \mathrm{H}, \mathrm{CH} \mathrm{H}_{2} \mathrm{Cl}\right), 7.30(\mathrm{~d}$, $1 \mathrm{H}, 8-\mathrm{H}), 7.65-7.75(\mathrm{~m}, 2 \mathrm{H}, 5-\mathrm{H}, 7-\mathrm{H}), 8.70(\mathrm{~m}, 1 \mathrm{H}$, $\mathrm{NH}), 8.80$ (s, 1H, 4-H). Anal. $\left(\mathrm{C}_{16} \mathrm{H}_{16} \mathrm{NO}_{3} \mathrm{Cl}\right) \mathrm{C}, \mathrm{H}, \mathrm{N}$.

$\mathrm{N}$-Cyclohexyl-6-(chloromethyl)-2-oxo-2H-1-benzopyran3-carboxamide (18). This was prepared according to the general procedure (yield: 54\%): mp 220-223 ${ }^{\circ} \mathrm{C}$ (ethyl acetate:petroleum ether $\left.40-60^{\circ} \mathrm{C}\right)$; IR $3327(\mathrm{~N}-\mathrm{H})$, 2930, 2854 (C-H aliph), 1733 (C=O lactone), 1650 ( $\mathrm{C}=\mathrm{O}$ amide $), 1618,1580,1536,1489,1445,1252,1223$ $\mathrm{cm}^{-1} ;{ }^{1} \mathrm{H}$ NMR $\left(80 \mathrm{MHz}, \mathrm{CDCl}_{3}, \mathrm{TMS}\right), \delta 1.20-1.95$ $\left(\mathrm{m}, 10 \mathrm{H},\left(\mathrm{CH}_{2}\right)_{5}\right), 3.95(\mathrm{~m}, 1 \mathrm{H}, \mathrm{CH}), 4.60(\mathrm{~s}, 2 \mathrm{H}$, $\left.\mathrm{CH}_{2} \mathrm{Cl}\right), 7.35(\mathrm{~d}, 1 \mathrm{H}, 8-\mathrm{H}), 7.55-7.65(\mathrm{~d}+\mathrm{s}, 2 \mathrm{H}, 5-\mathrm{H}$, 7-H), $8.70(\mathrm{~m}, 1 \mathrm{H}, \mathrm{NH}), 8.85$ (s, 1H, 4-H). Anal. $\left(\mathrm{C}_{17} \mathrm{H}_{18} \mathrm{NO}_{3} \mathrm{Cl}\right) \mathrm{C}, \mathrm{H}, \mathrm{N}$.

$\mathrm{N}$-Cycloheptyl-6-(chloromethyl)-2-oxo-2H-1-benzopyran3-carboxamide (19). This was prepared according to the general procedure (yield: $38 \%$ ): mp $207-211^{\circ} \mathrm{C}$ (ethyl acetate:petroleum ether $\left.40-60{ }^{\circ} \mathrm{C}\right)$; IR $3324(\mathrm{~N}-\mathrm{H})$, 2928, 2851 (C-H aliph), 1730 (C=O lactone), 1647 (C=O amide), 1618, 1579, 1535, $1173 \mathrm{~cm}^{-1} ;{ }^{1} \mathrm{H}$ NMR (80 MHz, $\left.\mathrm{CDCl}_{3}, \mathrm{TMS}\right), \delta 1.20-2.00\left(\mathrm{~m}, 12 \mathrm{H},\left(\mathrm{CH}_{2}\right)_{6}\right)$, $4.05(\mathrm{~m}, 1 \mathrm{H}, \mathrm{CH}), 4.65\left(\mathrm{~s}, 2 \mathrm{H}, \mathrm{CH} \mathrm{H}_{2} \mathrm{Cl}\right), 7.30(\mathrm{~d}, 1 \mathrm{H}, 8-$ $\mathrm{H})$, 7.60-7.75 (m, 2H, 5-H, 7-H), 8.70 (m, 1H, NH), 8.80 (s, 1H, 4-H). Anal. $\left(\mathrm{C}_{18} \mathrm{H}_{20} \mathrm{NO}_{3} \mathrm{Cl}\right) \mathrm{C}, \mathrm{H}, \mathrm{N}$.

N-Cyclooctyl-6-(chloromethyl)-2-oxo-2H-1-benzopyran3-carboxamide (20). This was prepared according to the general procedure (yield: 32\%): mp 192-195 ${ }^{\circ} \mathrm{C}$ (ethyl acetate:petroleum ether $\left.40-60^{\circ} \mathrm{C}\right)$; IR $3326(\mathrm{~N}-\mathrm{H})$, 3062, 3034 (C-H arom), 2923, 2855 (C-H aliph), 1728 ( $\mathrm{C}=\mathrm{O}$ lactone), 1647 ( $\mathrm{C}=\mathrm{O}$ amide), 1618, 1579, 1533, 1363, 1243, $1174 \mathrm{~cm}^{-1} ;{ }^{1} \mathrm{H}$ NMR $\left(400 \mathrm{MHz}, \mathrm{CDCl}_{3}\right.$, TMS $), \delta 1.60-1.94\left(\mathrm{~m}, 14 \mathrm{H},\left(\mathrm{CH}_{2}\right)_{7}\right), 4.18-4.20(\mathrm{~m}, 1 \mathrm{H}$, $\mathrm{CH}), 4.66\left(\mathrm{~s}, 2 \mathrm{H}, \mathrm{CH}_{2} \mathrm{Cl}\right), 7.41(\mathrm{~d}, 1 \mathrm{H}, 8-\mathrm{H}), 7.67-7.69$ $(\mathrm{d}+\mathrm{s}, 2 \mathrm{H}, 5-\mathrm{H}, 7-\mathrm{H}), 8.78-8.80(\mathrm{~m}, 1 \mathrm{H}, \mathrm{NH}), 8.88(\mathrm{~s}$, $1 \mathrm{H}, 4-\mathrm{H})$. Anal. $\left(\mathrm{C}_{19} \mathrm{H}_{22} \mathrm{NO}_{3} \mathrm{Cl}\right) \mathrm{C}, \mathrm{H}, \mathrm{N}$.

N-Cyclododecyl-6-(chloromethyl)-2-oxo-2H-1-benzopyran3-carboxamide (21). This was prepared according to the general procedure (yield: $41 \%$ ): $\mathrm{mp} 224-226^{\circ} \mathrm{C}$ (ethyl acetate:petroleum ether $\left.40-60^{\circ} \mathrm{C}\right)$; IR $3329(\mathrm{~N}-\mathrm{H})$, 2944, 2863, 2840 (C-H aliph), 1731 (C=O lactone), 1649 ( $\mathrm{C}=\mathrm{O}$ amide), 1619, 1580, 1541, $1470 \mathrm{~cm}^{-1} ;{ }^{1} \mathrm{H}$ NMR (400 MHz, $\left.\mathrm{CDCl}_{3}, \mathrm{TMS}\right), \delta 1.25-1.80(\mathrm{~m}, 22 \mathrm{H}$, $\left.\left(\mathrm{CH}_{2}\right)_{11}\right), 4.24-4.26(\mathrm{~m}, 1 \mathrm{H}, \mathrm{CH}), 4.66\left(\mathrm{~s}, 2 \mathrm{H}, \mathrm{CH} \mathrm{H}_{2} \mathrm{Cl}\right)$, $7.41(\mathrm{~d}, 1 \mathrm{H}, 8-\mathrm{H}), 7.68-7.70(\mathrm{~d}+\mathrm{s}, 2 \mathrm{H}, 5-\mathrm{H}, 7-\mathrm{H}), 8.65-$ $8.67(\mathrm{~m}, 1 \mathrm{H}, \mathrm{NH}), 8.88(\mathrm{~s}, 1 \mathrm{H}, 4-\mathrm{H})$. Anal. $\left(\mathrm{C}_{23} \mathrm{H}_{30}\right.$ $\left.\mathrm{NO}_{3} \mathrm{Cl}\right) \mathrm{C}, \mathrm{H}, \mathrm{N}$.

$\mathrm{N}$-Piperid-1-yl-6-(chloromethyl)-2-oxo-2H-1-benzopyran3-carboxamide (22). This was prepared according to the general procedure (yield: $37 \%$ ): mp 197-200 ${ }^{\circ} \mathrm{C}$ (ethyl acetate:petroleum ether $\left.40-60^{\circ} \mathrm{C}\right)$; IR $3273(\mathrm{~N}-\mathrm{H}), 3042$ (C-H arom), 2941, 2856, 2804 (C-H aliph), 1735 (C=O lactone), 1662 ( $\mathrm{C}=\mathrm{O}$ amide), 1580, 1539, 1273, 1247, $1164 \mathrm{~cm}^{-1} ;{ }^{1} \mathrm{H}$ NMR (400 MHz, $\mathrm{CDCl}_{3}$, TMS), $\delta 1.46$ $1.49\left(\mathrm{~m}, 2 \mathrm{H}, \mathrm{N}\left(\mathrm{C}_{2} \mathrm{H}_{4}\right)_{2} \mathrm{CH}_{2}\right), 1.75-1.80\left(\mathrm{~m}, 4 \mathrm{H}, \mathrm{N}\left(\mathrm{CH}_{2}\right.\right.$ $\left.\left.\mathrm{CH}_{2}\right)_{2}\right), 2.90\left(\mathrm{t}, 4 \mathrm{H}, \mathrm{N}\left(\mathrm{CH}_{2} \mathrm{CH}_{2}\right)_{2}\right), 4.65$ (s, $2 \mathrm{H}, \mathrm{CH} \mathrm{CH}_{2} \mathrm{Cl}$, $7.41(\mathrm{~d}, 1 \mathrm{H}, 8-\mathrm{H}), 7.68-7.71(\mathrm{~d}+\mathrm{s}, 2 \mathrm{H}, 5-\mathrm{H}, 7-\mathrm{H}), 8.94$ $(\mathrm{s}, 1 \mathrm{H}, 4-\mathrm{H}), 9.52(\mathrm{~s}, 1 \mathrm{H}, \mathrm{NH})$. Anal. $\left(\mathrm{C}_{16} \mathrm{H}_{17} \mathrm{~N}_{2} \mathrm{O}_{3} \mathrm{Cl}\right)$ C, H, N. 
$N, N^{\prime}$-Dipropyl-6-(chloromethyl)-2-oxo-2H-1-benzopyran3-carboxamide (23). This was prepared according to the general procedure (yield: $41 \%$ ): $\mathrm{mp} 118-124^{\circ} \mathrm{C}$ (ethyl acetate:petroleum ether $\left.40-60^{\circ} \mathrm{C}\right)$; IR $3045 \quad(\mathrm{C}-\mathrm{H}$ arom), 2970, 2932, 2873 (C-H aliph), 1715 (C=O lactone), 1631 ( $\mathrm{C}=\mathrm{O}$ amide) $\mathrm{cm}^{-1} ;{ }^{1} \mathrm{H}$ NMR $(80 \mathrm{MHz}$, $\left.\mathrm{CDCl}_{3}, \mathrm{HMDS}\right), \delta 0.70\left(\mathrm{~m}, 6 \mathrm{H}, 2 * \mathrm{CH}_{3}\right), 1.55(\mathrm{~m}, 4 \mathrm{H}$, 2* $\mathrm{CH}_{2}-\mathrm{CH}_{2}-\mathrm{CH}_{3}$ ), 3.10 (t, $2 \mathrm{H}, \mathrm{N}-\mathrm{CH}_{2}{ }_{\mathrm{a}} \mathrm{CH}_{2} \mathrm{CH}_{3}$ ), 3.40 (t, $\left.2 \mathrm{H}, \mathrm{N}-\mathrm{CH}_{2} \mathrm{~b}_{\mathrm{b}} \mathrm{CH}_{2} \mathrm{CH}_{3}\right), 4.55$ (s, $\left.2 \mathrm{H}, \mathrm{CH} 2 \mathrm{Cl}\right), 7.25$ (d, $1 \mathrm{H}, 8-\mathrm{H}), 7.45$ (s, 1H, 5-H), $7.50(\mathrm{~d}, 1 \mathrm{H}, 7-\mathrm{H}), 7.65$ (s, $1 \mathrm{H}, 4-\mathrm{H})$. Anal. $\left(\mathrm{C}_{17} \mathrm{H}_{20} \mathrm{NO}_{3} \mathrm{Cl}\right) \mathrm{C}, \mathrm{H}, \mathrm{N}$.

6-(Chloromethyl)-2-oxo-3-piperidinocarbonyl-2H-1-benzopyran-3-carboxamide (24). This was prepared according to the general procedure (yield: $34 \%$ ): $m p \quad 153-155^{\circ} \mathrm{C}$ (ethyl acetate:petroleum ether 40-60 $\left.{ }^{\circ} \mathrm{C}\right)$; IR $3044(\mathrm{C}-\mathrm{H}$ arom), 2944, 2856 (C-H aliph), 1714 (C=O lactone), 1640 (C=O amide), 1580, 1445, 1255, 1237, $1178 \mathrm{~cm}^{-1}$; ${ }^{1} \mathrm{H}$ NMR (400 MHz, CDCl 3 , TMS ), $\delta 1.60-1.68(\mathrm{~m}, 6 \mathrm{H}$, $\left.\left(\mathrm{CH}_{2} \mathrm{CH}_{2}\right)_{2} \mathrm{CH}_{2}\right), 3.30-3.71\left(\mathrm{~m}, 4 \mathrm{H},\left(\mathrm{CH}_{2} \mathrm{CH}_{2}\right)_{2}\right), 4.63$ (s, 2H, $\left.\mathrm{CH}_{2} \mathrm{Cl}\right), 7.35$ (d, 1H, 8-H), 7.55 (s, 1H, 5-H), 7.59 $(\mathrm{d}, 1 \mathrm{H}, 7-\mathrm{H}), 7.83$ (s, $1 \mathrm{H}, 4-\mathrm{H})$. Anal. $\left(\mathrm{C}_{16} \mathrm{H}_{16} \mathrm{NO}_{3} \mathrm{Cl}\right) \mathrm{C}$, $\mathrm{H}, \mathrm{N}$.

6-(Chloromethyl)-3-morpholinocarbonyl-2-oxo-2 $H$-1-benzopyran-3-carboxamide (25). This was prepared according to the general procedure (yield: $37 \%$ ): mp $210-212^{\circ} \mathrm{C}$ (ethyl acetate:petroleum ether $40-60^{\circ} \mathrm{C}$ ); IR 3044, 3027 (C-H arom), 2992, 2922, 2858 (C-H aliph), 1718 (C=O lactone), 1626 ( $\mathrm{C}=\mathrm{O}$ amide), 1582, 1469, 1275, 1248, $1178 \mathrm{~cm}^{-1} ;{ }^{1} \mathrm{H} \mathrm{NMR}\left(400 \mathrm{MHz}, \mathrm{CDCl}_{3}, \mathrm{TMS}\right), \delta 3.39-$ $3.80\left(\mathrm{~m}, 8 \mathrm{H},\left(\mathrm{CH}_{2} \mathrm{CH}_{2}\right)_{2}\right), 4.64\left(\mathrm{~s}, 2 \mathrm{H}, \mathrm{CH} \mathrm{H}_{2} \mathrm{Cl}\right), 7.37$ (d, $1 \mathrm{H}, 8-\mathrm{H}), 7.57$ (s, 1H, 5-H), 7.62 (d, 1H, 7-H), 7.94 (s, $1 \mathrm{H}, 4-\mathrm{H})$. Anal. $\left(\mathrm{C}_{15} \mathrm{H}_{14} \mathrm{NO}_{4} \mathrm{Cl}\right) \mathrm{C}, \mathrm{H}, \mathrm{N}$.

2-Nitrophenyl 6-(chloromethyl)-2-oxo-2H-1-benzopyran3-carboxylate (26). This was prepared according to the general procedure (yield: $37 \%$ ): $\mathrm{mp} 163-164{ }^{\circ} \mathrm{C}$ (acetonitrile); IR 3077 (C-H arom), 1768 (C=O ester), 1727 (C=O lactone), 1609, 1576, 1548, 1374, 1349, 1242, 1204 $\mathrm{cm}^{-1} ;{ }^{1} \mathrm{H}$ NMR (400 MHz, $\mathrm{CDCl}_{3}$, TMS), $\delta 4.67$ (s, 2H, $\left.\mathrm{CH}_{2} \mathrm{Cl}\right), 7.41-7.51\left(\mathrm{~m}, 3 \mathrm{H}, 8-\mathrm{H}, 4^{\prime}-\mathrm{H}, 6^{\prime}-\mathrm{H}\right), 7.72-7.77$ $\left(\mathrm{m}, 3 \mathrm{H}, 5-\mathrm{H}, 7-\mathrm{H}, 5^{\prime}-\mathrm{H}\right), 8.18\left(\mathrm{dd}, 1 \mathrm{H}, 3^{\prime}-\mathrm{H}\right), 8.79$ (s, $1 \mathrm{H}, 4-\mathrm{H})$. Anal. $\left(\mathrm{C}_{17} \mathrm{H}_{10} \mathrm{NO}_{6} \mathrm{Cl}\right) \mathrm{C}, \mathrm{H}, \mathrm{N}$.

3-Trifluoromethylphenyl 6-(chloromethyl)-2-oxo-2H-1benzopyran-3-carboxylate (27). This was prepared according to the general procedure (yield: 46\%): $\mathrm{mp}$ 162-163 ${ }^{\circ} \mathrm{C}$ (acetonitrile); IR 3069 (C-H arom), 1772 ( $\mathrm{C}=\mathrm{O}$ ester $), 1756$ ( $\mathrm{C}=\mathrm{O}$ lactone $), 1621,1574,1336$, 1239, 1223, $1200 \mathrm{~cm}^{-1}$; ${ }^{1} \mathrm{H}$ NMR $\left(80 \mathrm{MHz}, \mathrm{CDCl}_{3}\right.$, $\mathrm{HMDS}), \delta 4.55\left(\mathrm{~s}, 2 \mathrm{H}, \mathrm{CH}_{2} \mathrm{Cl}\right), 7.15-7.40(\mathrm{~m}, 5 \mathrm{H}$, $\left.\mathrm{C}_{6} \mathrm{H}_{4}, 8-\mathrm{H}\right), 7.55$ (s, 1H, 5-H), 7.60 (d, 1H, 7-H), 8.65 (s, 1H, 4-H). Anal. $\left(\mathrm{C}_{18} \mathrm{H}_{10} \mathrm{O}_{4} \mathrm{~F}_{3} \mathrm{Cl}\right) \mathrm{C}, \mathrm{H}$.

3-Methoxyphenyl 6-(chloromethyl)-2-oxo-2H-1-benzopyran-3-carboxylate (28). This was prepared according to the general procedure (yield: $47 \%$ ): $\mathrm{mp} 133-135^{\circ} \mathrm{C}$ $\left(\mathrm{CHCl}_{3}\right.$ :petroleum ether $\left.40-60^{\circ} \mathrm{C}\right)$; IR $3063(\mathrm{C}-\mathrm{H}$ arom), 1775 ( $\mathrm{C}=\mathrm{O}$ ester), 1757 ( $\mathrm{C}=\mathrm{O}$ lactone), 1622, 1609, 1574, 1489, 1377, 1245, 1224, $1147 \mathrm{~cm}^{-1} ;{ }^{1} \mathrm{H}$ NMR (80 MHz, CDCl 3 , HMDS), $\delta 3.70\left(\mathrm{~s}, 3 \mathrm{H}, \mathrm{OCH}_{3}\right)$, 4.55 (s, 2H, $\left.\mathrm{CH}_{2} \mathrm{Cl}\right), 6.7-6.8\left(\mathrm{~m}, 3 \mathrm{H}, 2^{\prime}-\mathrm{H}, 4^{\prime}-\mathrm{H}, 6^{\prime}-\mathrm{H}\right)$, $7.10-7.35\left(\mathrm{~m}, 2 \mathrm{H}, 8-\mathrm{H}, 5^{\prime}-\mathrm{H}\right), 7.55(\mathrm{~s}, 1 \mathrm{H}, 5-\mathrm{H}), 7.60(\mathrm{~d}$, $1 \mathrm{H}, 7-\mathrm{H}), 8.60(\mathrm{~s}, 1 \mathrm{H}, 4-\mathrm{H})$. Anal. $\left(\mathrm{C}_{18} \mathrm{H}_{13} \mathrm{O}_{5} \mathrm{Cl}\right) \mathrm{C}, \mathrm{H}$.

3-Fluorophenyl 6-(chloromethyl)-2-oxo-2H-1-benzopyran3-carboxylate (29). This was prepared according to the general procedure (yield: $52 \%$ ): $\mathrm{mp} 195-197^{\circ} \mathrm{C}$ (acetonitrile); IR 3070 (C-H arom), 1774 ( $\mathrm{C}=\mathrm{O}$ ester), 1756 $(\mathrm{C}=\mathrm{O}$ lactone $), 1709,1622,1609,1573,1486,1444$, 1380, 1240, $1223 \mathrm{~cm}^{-1}$; ${ }^{1} \mathrm{H}$ NMR $\left(80 \mathrm{MHz}, \mathrm{CDCl}_{3}\right.$, HMDS), $\delta 4.55\left(\mathrm{~s}, 2 \mathrm{H}, \mathrm{CH}_{2} \mathrm{Cl}\right), 6.90-7.35(\mathrm{~m}, 5 \mathrm{H}$, $\left.\mathrm{C}_{6} \mathrm{H}_{4}, 8-\mathrm{H}\right), 7.60(\mathrm{~s}, 1 \mathrm{H}, 5-\mathrm{H}), 7.65(\mathrm{~d}, 1 \mathrm{H}, 7-\mathrm{H}), 8.60$ (s, $1 \mathrm{H}, 4-\mathrm{H})$. Anal. $\left(\mathrm{C}_{17} \mathrm{H}_{10} \mathrm{O}_{4} \mathrm{FCl}\right) \mathrm{C}, \mathrm{H}$.

3-Bromophenyl 6-(chloromethyl)-2-oxo-2H-1-benzopyran3-carboxylate (30). This was prepared according to the general procedure (yield: $37 \%$ ): $\mathrm{mp} 177-178^{\circ} \mathrm{C}$ (acetonitrile), IR 3086 (C-H arom), 3062 (C-H arom), 1771 $(\mathrm{C}=\mathrm{O}$ ester $), 1724$ ( $\mathrm{C}=\mathrm{O}$ lactone $), 1619,1574,1468$, $1375,1244 \mathrm{~cm}^{-1} ;{ }^{1} \mathrm{H}$ NMR $\left(80 \mathrm{MHz}, \mathrm{CDCl}_{3}, \mathrm{HMDS}\right)$, $\delta 4.55\left(\mathrm{~s}, 2 \mathrm{H}, \mathrm{CH}_{2} \mathrm{Cl}\right), 7.05-7.40\left(\mathrm{~m}, 5 \mathrm{H}, \mathrm{C}_{6} \mathrm{H}_{4}, 8-\mathrm{H}\right)$, 7.60-7.70 (s+d, 2H, 5-H, 7-H), 8.60 (s, 1H, 4-H). Anal. $\left(\mathrm{C}_{17} \mathrm{H}_{10} \mathrm{O}_{4} \mathrm{BrCl}\right) \mathrm{C}, \mathrm{H}$.

3-Chloro-5-methoxyphenyl 6-(chloromethyl)-2-oxo-2H-1benzopyran-3-carboxylate (32). This was prepared according to the general procedure (yield: $50 \%$ ): $\mathrm{mp} 184$ $185^{\circ} \mathrm{C}$ (acetonitrile); IR 3064 (C-H arom), $1779(\mathrm{C}=\mathrm{O}$ ester), 1758 ( $\mathrm{C}=\mathrm{O}$ lactone), 1621, 1573, 1377, 1242, $1222,1150 \mathrm{~cm}^{-1} ;{ }^{1} \mathrm{H}$ NMR (80 MHz, $\left.\mathrm{CDCl}_{3}, \mathrm{HMDS}\right), \delta$ $3.70\left(\mathrm{~s}, 3 \mathrm{H}, \mathrm{OCH}_{3}\right), 4.55\left(\mathrm{~s}, 2 \mathrm{H}, \mathrm{CH}_{2} \mathrm{Cl}\right), 6.60-6.90(\mathrm{~m}$, $\left.3 \mathrm{H}, \mathrm{C}_{6} \mathrm{H}_{3}\right), 7.30(\mathrm{~d}, 1 \mathrm{H}, 8-\mathrm{H}), 7.60(\mathrm{~s}, 1 \mathrm{H}, 5-\mathrm{H}), 765(\mathrm{~d}$, $1 \mathrm{H}, 7-\mathrm{H}), 8.60$ (s, $1 \mathrm{H}, 4-\mathrm{H})$. Anal. $\left(\mathrm{C}_{18} \mathrm{H}_{12} \mathrm{O}_{5} \mathrm{Cl}_{2}\right) \mathrm{C}, \mathrm{H}$.

2,3-Dichlorophenyl 6-(chloromethyl)-2-oxo-2H-1-benzopyran-3-carboxylate (33). This was prepared according to the general procedure (yield: $34 \%$ ): $\mathrm{mp} 173-174^{\circ} \mathrm{C}$ (ethyl acetate); IR 3051 ( $\mathrm{C}-\mathrm{H}$ arom), 1771 ( $\mathrm{C}=\mathrm{O}$ ester), 1723 (C=O lactone), 1620, 1572, 1450, 1433, 1374, 1238, $1215 \mathrm{~cm}^{-1} ;{ }^{1} \mathrm{H}$ NMR (400 MHz, $\left.\mathrm{CDCl}_{3}, \mathrm{TMS}\right), \delta 4.66$ (s, 2H, $\left.\mathrm{CH}_{2} \mathrm{Cl}\right), 7.25-7.31\left(\mathrm{~m}, 2 \mathrm{H}, 5^{\prime}-\mathrm{H}, 6^{\prime}-\mathrm{H}\right), 7.41-7.44$ (m, 2H, 8-H, 4'-H), 7.72-7.74 (s + d, 2H, 5-H, 7-H), 8.80 (s, $1 \mathrm{H}, 4-\mathrm{H})$. Anal. $\left(\mathrm{C}_{17} \mathrm{H}_{9} \mathrm{O}_{4} \mathrm{Cl}_{3}\right) \mathrm{C}, \mathrm{H}$.

2,5-Dichlorophenyl 6-(chloromethyl)-2-oxo-2H-1-benzopyran-3-carboxylate (34). This was prepared according to the general procedure (yield: $40 \%$ ): $\mathrm{mp} 197-199{ }^{\circ} \mathrm{C}$ (ethyl acetate); IR 3092, 3045 (C-H arom), $1769(\mathrm{C}=\mathrm{O}$ ester), 1721 ( $\mathrm{C}=\mathrm{O}$ lactone), 1621, 1573, 1474, 1372, $1241,1220 \mathrm{~cm}^{-1}$; ${ }^{1} \mathrm{H}$ NMR $\left(400 \mathrm{MHz}, \mathrm{CDCl}_{3}, \mathrm{TMS}\right)$, $\delta 4.66\left(\mathrm{~s}, 2 \mathrm{H}, \mathrm{CH}_{2} \mathrm{Cl}\right), 7.25\left(\mathrm{~d}, 1 \mathrm{H}, 4^{\prime}-\mathrm{H}\right), 7.35(\mathrm{~d}, 1 \mathrm{H}$, $\left.6^{\prime}-\mathrm{H}\right), 7.41-7.44\left(\mathrm{~m}, 2 \mathrm{H}, 8-\mathrm{H}, 3^{\prime}-\mathrm{H}\right), 7.72-7.74(\mathrm{~s}+\mathrm{d}$, $2 \mathrm{H}, 5-\mathrm{H}, 7-\mathrm{H}), 8.79(\mathrm{~s}, 1 \mathrm{H}, 4-\mathrm{H})$. Anal. $\left(\mathrm{C}_{17} \mathrm{H}_{9} \mathrm{O}_{4} \mathrm{Cl}_{3}\right) \mathrm{C}$, H.

2,6-Dichlorophenyl 6-(chloromethyl)-2-oxo-2H-1-benzopyran-3-carboxylate (35). This was prepared according to the general procedure (yield: $43 \%$ ): $\mathrm{mp} 177-178^{\circ} \mathrm{C}$ (ethyl acetate); IR 3074 ( $\mathrm{C}-\mathrm{H}$ arom), 1773 ( $\mathrm{C}=\mathrm{O}$ ester), 1720 (C=O lactone), 1619, 1571, 1488, 1450, 1376, 1228 $\mathrm{cm}^{-1},{ }^{1} \mathrm{H}$ NMR $\left(400 \mathrm{MHz}, \mathrm{CDCl}_{3}, \mathrm{TMS}\right), \delta 4.66(\mathrm{~s}, 2 \mathrm{H}$, $\left.\mathrm{CH}_{2} \mathrm{Cl}\right), 7.22\left(\mathrm{dd}, 1 \mathrm{H}, 4^{\prime}-\mathrm{H}\right), 7.40-7.43\left(\mathrm{~m}, 3 \mathrm{H}, 8-\mathrm{H}, 3^{\prime}-\right.$ $\left.\mathrm{H}, 5^{\prime}-\mathrm{H}\right), 7.72-7.74(\mathrm{~s}+\mathrm{d}, 2 \mathrm{H}, 5-\mathrm{H}, 7-\mathrm{H}), 8.55$ (s, 1H, 4$\mathrm{H})$. Anal. $\left(\mathrm{C}_{17} \mathrm{H}_{9} \mathrm{O}_{4} \mathrm{Cl}_{3}\right) \mathrm{C}, \mathrm{H}$. 
3,5-Dichlorophenyl 6-(chloromethyl)-2-oxo-2H-1-benzopyran-3-carboxylate (36). This was prepared according to the general procedure (yield: $48 \%$ ): $\mathrm{mp} 208-209^{\circ} \mathrm{C}$ $\left(\mathrm{CHCl}_{3}\right)$; IR $3069(\mathrm{C}-\mathrm{H}$ arom $), 1778(\mathrm{C}=\mathrm{O}$ ester $), 1762$ $(\mathrm{C}=\mathrm{O}$ lactone $), 1713,1620,1581,1571,1376,1241$ $\mathrm{cm}^{-1} ;{ }^{1} \mathrm{H}$ NMR $\left(400 \mathrm{MHz}, \mathrm{CDCl}_{3}, \mathrm{TMS}\right), \delta 4.66(\mathrm{~s}, 2 \mathrm{H}$, $\left.\mathrm{CH}_{2} \mathrm{Cl}\right), 7.21\left(\mathrm{~s}, 2 \mathrm{H}, 2^{\prime}-\mathrm{H}, 6^{\prime}-\mathrm{H}\right), 7.31\left(\mathrm{~s}, 1 \mathrm{H}, 4^{\prime}-\mathrm{H}\right), 7.41$ $(\mathrm{d}, 1 \mathrm{H}, 8-\mathrm{H}), 7.70(\mathrm{~s}, 1 \mathrm{H}, 5-\mathrm{H}), 7.73(\mathrm{~d}, 1 \mathrm{H}, 7-\mathrm{H}), 8.70$ (s, $1 \mathrm{H}, 4-\mathrm{H})$. Anal. $\left(\mathrm{C}_{17} \mathrm{H}_{9} \mathrm{O}_{4} \mathrm{Cl}_{3}\right) \mathrm{C}, \mathrm{H}$.

$S$-Phenyl 6-(chloromethyl)-2-oxo-2H-1-benzopyran-3-carbothioate (39). This was prepared according to the general procedure (yield: $43 \%$ ): $\mathrm{mp} 164-166^{\circ} \mathrm{C}$ (acetonitrile); IR 3060, $3042(\mathrm{C}-\mathrm{H}$ arom), $1724(\mathrm{C}=\mathrm{O}$ lactone), 1655 $(\mathrm{C}=\mathrm{O}$ thioester $), 1568,1178 \mathrm{~cm}^{-1} ;{ }^{1} \mathrm{H}$ NMR $(80 \mathrm{MHz}$, $\mathrm{CDCl}_{3}, \mathrm{HMDS}$ ), $\delta 4.55$ (s, 2H, $\mathrm{CH}_{2} \mathrm{Cl}$ ), 7.30-7.60 (m, $\left.6 \mathrm{H}, 8-\mathrm{H}, \mathrm{C}_{6} H_{5}\right), 7.60(\mathrm{~s}, 1 \mathrm{H}, 5-\mathrm{H}), 7.65(\mathrm{~d}, 1 \mathrm{H}, 7-\mathrm{H})$, 8.50 (s, $1 \mathrm{H}, 4-\mathrm{H})$. Anal. $\left(\mathrm{C}_{17} \mathrm{H}_{11} \mathrm{O}_{3} \mathrm{SCl}\right) \mathrm{C}, \mathrm{H}, \mathrm{S}$.

$\mathrm{N}$-(3'-Chlorophenyl)-6-(chloromethyl)-2-oxo-2H-1-benzopyran-3-carboxamide (40). This was prepared according to the general procedure (yield: $38 \%$ ): $\mathrm{mp} 219-220^{\circ} \mathrm{C}$ (acetone); IR 3225 (N-H amide), 3080, 3040 (C-H arom), $1707(\mathrm{C}=\mathrm{O}$ lactone $), 1664(\mathrm{C}=\mathrm{O}$ amide $), 1591$, $1573,1542,1426,1253 \mathrm{~cm}^{-1} ;{ }^{1} \mathrm{H}$ NMR $(400 \mathrm{MHz}$, $\left.\mathrm{CDCl}_{3}, \mathrm{TMS}\right), \delta 4.68\left(\mathrm{~s}, 2 \mathrm{H}, \mathrm{CH}_{2} \mathrm{Cl}\right), 7.13-7.16(\mathrm{~m}, 1 \mathrm{H}$, $\left.4^{\prime}-\mathrm{H}\right), 7.31\left(\mathrm{dd}, 1 \mathrm{H}, 5^{\prime}-\mathrm{H}\right), 7.46(\mathrm{~d}, 1 \mathrm{H}, 8-\mathrm{H}), 7.54-7.56$ $\left(\mathrm{m}, 1 \mathrm{H}, 6^{\prime}-\mathrm{H}\right), 7.73-7.76(\mathrm{~s}+\mathrm{d}, 2 \mathrm{H}, 5-\mathrm{H}, 7-\mathrm{H}), 7.89-7.90$ (m, $\left.1 \mathrm{H}, 2^{\prime}-\mathrm{H}\right), 9.00(\mathrm{~s}, 1 \mathrm{H}, 4-\mathrm{H})$. Anal. $\left(\mathrm{C}_{17} \mathrm{H}_{11} \mathrm{NO}_{3} \mathrm{Cl}_{2}\right)$ $\mathrm{C}, \mathrm{H}, \mathrm{N}$.

$S$-(3'-Chlorophenyl) 6-(chloromethyl)-2-oxo-2H-1-benzopyran-3-carbothioate (41). This was prepared according to the general procedure (yield: $63 \%$ ): $\mathrm{mp} 194-195^{\circ} \mathrm{C}$ (acetonitrile); IR 3070, $3045(\mathrm{C}-\mathrm{H}$ arom $), 1712(\mathrm{C}=\mathrm{O}$ lactone), $1652(\mathrm{C}=\mathrm{O}$ thioester $), 1568,1180 \mathrm{~cm}^{-1} ;{ }^{1} \mathrm{H}$ NMR (400 MHz, $\mathrm{CDCl}_{3}$, TMS), $\delta 4.66$ (s, $2 \mathrm{H}, \mathrm{CH}_{2} \mathrm{Cl}$ ), 7.40-7.45 (m, 4H, 8-H, 4'-H, 5'-H, 6'-H), $7.52\left(\mathrm{~s}, 1 \mathrm{H}, 2^{\prime}-\right.$ H), 7.71-7.72 (s+d, 2H, 5-H, 7-H), $8.55(\mathrm{~s}, 1 \mathrm{H}, 4-\mathrm{H})$. Anal. $\left(\mathrm{C}_{17} \mathrm{H}_{10} \mathrm{O}_{3} \mathrm{SCl}_{2}\right) \mathrm{C}, \mathrm{H}, \mathrm{S}$.

Phenyl 2-oxo-2H-1-benzopyran-3-carboxylate (43). This was prepared according to the general procedure (yield: $80 \%$ ): mp $155-157^{\circ} \mathrm{C}$ (ethyl acetate); IR $3060(\mathrm{C}-\mathrm{H}$ arom), $1768(\mathrm{C}=\mathrm{O}$ ester $), 1741 \quad(\mathrm{C}=\mathrm{O}$ lactone $), 1715$, $1610,1243 \mathrm{~cm}^{-1} ;{ }^{1} \mathrm{H}$ NMR (400 MHz, $\left.\mathrm{CDCl}_{3}, \mathrm{TMS}\right), \delta$ 7.23-7.46 (m, 7H, $\left.\mathrm{C}_{6} H_{5}, 6-\mathrm{H}, 8-\mathrm{H}\right), 7.66-7.72(\mathrm{~m}, 2 \mathrm{H}, 5-$ $\mathrm{H}, 7-\mathrm{H}), 8.75$ (s, $1 \mathrm{H}, 4-\mathrm{H})$. Anal. $\left(\mathrm{C}_{16} \mathrm{H}_{10} \mathrm{O}_{4}\right) \mathrm{C}, \mathrm{H}$.

Phenyl 6-(acetoxymethyl)-2-oxo-2H-1-benzopyran-3-carboxylate (44). This was prepared according to the general procedure (yield: $46 \%$ ): $\mathrm{mp} 188-190^{\circ} \mathrm{C}$ (ethyl acetate); IR 3067 ( $\mathrm{C}-\mathrm{H}$ arom), $1733(\mathrm{C}=\mathrm{O}$ esters and lactone), $1628,1580,1493,1250 \mathrm{~cm}^{-1} ;{ }^{1} \mathrm{H} \quad \mathrm{NMR}(80 \mathrm{MHz}$, $\left.\mathrm{CDCl}_{3}, \mathrm{TMS}\right), \delta 2.05\left(\mathrm{~s}, 3 \mathrm{H}, \mathrm{CH}_{3}\right), 5.10\left(\mathrm{~s}, 2 \mathrm{H}, \mathrm{CH}_{2}\right)$, 7.10-7.40 (m, 6H, $\left.\mathrm{C}_{6} \mathrm{H}_{5}, 8-\mathrm{H}\right), 7.60(\mathrm{~s}, 1 \mathrm{H}, 5-\mathrm{H}), 7.65(\mathrm{~d}$, $1 \mathrm{H}, 7-\mathrm{H}), 8.75(\mathrm{~s}, 1 \mathrm{H}, 4-\mathrm{H})$. Anal. $\left(\mathrm{C}_{19} \mathrm{H}_{14} \mathrm{O}_{6}\right) \mathrm{C}, \mathrm{H}$.

3-Chlorophenyl 6-methyl-2-oxo-2H-1-benzopyran-3-carboxylate (45). This was prepared according to the general procedure (yield: $45 \%$ ): $\mathrm{mp} 175-176^{\circ} \mathrm{C}$ (ethyl acetate); IR $3078(\mathrm{C}-\mathrm{H}$ arom $), 1771(\mathrm{C}=\mathrm{O}$ ester $), 1721(\mathrm{C}=\mathrm{O}$ lactone), 1624, 1577, 1492, $1223 \mathrm{~cm}^{-1} ;{ }^{1} \mathrm{H}$ NMR (400 MHz,
$\left.\mathrm{CDCl}_{3}, \mathrm{TMS}\right), \delta 2.45\left(\mathrm{~s}, 3 \mathrm{H}, \mathrm{CH}_{3}\right), 7.15-7.18(\mathrm{~m}, 1 \mathrm{H}$, $\left.4^{\prime}-\mathrm{H}\right), 7.27-7.32\left(\mathrm{~m}, 3 \mathrm{H}, 8-\mathrm{H}, 2^{\prime}-\mathrm{H}, 6^{\prime}-\mathrm{H}\right), 7.37(\mathrm{dd}, 1 \mathrm{H}$, 5'-H), $7.45(\mathrm{~s}, 1 \mathrm{H}, 5-\mathrm{H}), 7.51(\mathrm{~d}, 1 \mathrm{H}, 7-\mathrm{H}), 8.66(\mathrm{~s}, 1 \mathrm{H}$, 4-H). Anal. $\left(\mathrm{C}_{17} \mathrm{H}_{11} \mathrm{O}_{4} \mathrm{Cl}\right) \mathrm{C}, \mathrm{H}$.

3-Chlorophenyl 2-oxo-2H-1-benzopyran-3-carboxylate (46). This was prepared according to the general procedure (yield: $68 \%$ ): $\mathrm{mp} 170-171^{\circ} \mathrm{C}$ (ethyl acetate); IR 3086, $3061(\mathrm{C}-\mathrm{H}$ arom $), 1767(\mathrm{C}=\mathrm{O}$ ester $), 1721(\mathrm{C}=\mathrm{O}$ lactone), $1611,1299,1217 \mathrm{~cm}^{-1} ;{ }^{1} \mathrm{H}$ NMR $(400 \mathrm{MHz}$, $\left.\mathrm{CDCl}_{3}, \mathrm{TMS}\right), 7.15-7.18\left(\mathrm{~m}, 1 \mathrm{H}, 4^{\prime}-\mathrm{H}\right), 7.27-7.43(\mathrm{~m}$, $\left.5 \mathrm{H}, 6-\mathrm{H}, 8-\mathrm{H}, 2^{\prime}-\mathrm{H}, 5^{\prime}-\mathrm{H}, 6^{\prime}-\mathrm{H}\right), 7.67-7.74(\mathrm{~m}, 2 \mathrm{H}, 5-\mathrm{H}$, 7-H), 8.74 (s, $1 \mathrm{H}, 4-\mathrm{H})$. Anal. $\left(\mathrm{C}_{16} \mathrm{H}_{9} \mathrm{O}_{4} \mathrm{Cl}\right) \mathrm{C}, \mathrm{H}$.

3-Chlorophenyl 6-(acetoxymethyl)-2-oxo-2H-1-benzopyran-3-carboxylate (47). This was prepared according to the general procedure (yield: $30 \%$ ): $\mathrm{mp} 152-154^{\circ} \mathrm{C}$ (ethyl acetate:petroleum ether $\left.40-60^{\circ} \mathrm{C}\right)$; IR $3066(\mathrm{C}-\mathrm{H}$ arom), 1735 ( $\mathrm{C}=\mathrm{O}$ esters and lactone), 1628, 1579, 1474, $1249 \mathrm{~cm}^{-1} ;{ }^{1} \mathrm{H}$ NMR (400 MHz, $\mathrm{CDCl}_{3}$, TMS), $\delta 2.14$ (s, $\left.3 \mathrm{H}, \mathrm{CH}_{3}\right), 5.18\left(\mathrm{~s}, 2 \mathrm{H}, \mathrm{CH}_{2}\right), 7.15-7.18\left(\mathrm{~m}, 1 \mathrm{H}, 4^{\prime}-\right.$ $\mathrm{H})$, 7.27-7.30 (m, 2H, 2'-H, 6'-H), $7.36(\mathrm{~d}, 1 \mathrm{H}, 8-\mathrm{H})$, 7.39-7.43 (m, 1H, 5'-H), 7.69-7.72 (d + s, 2H, 5- H, 7-H), $8.73(\mathrm{~s}, 1 \mathrm{H}, 4-\mathrm{H})$. Anal. $\left(\mathrm{C}_{19} \mathrm{H}_{13} \mathrm{O}_{6} \mathrm{Cl}\right) \mathrm{C}, \mathrm{H}$.

\section{Enzymatic studies}

Bovine $\alpha-\mathrm{CT}$ and HLE were purchased from Sigma and Elastin Products Co., respectively. Their active site concentrations were determined by active-site titration. ${ }^{16}$ The proteases were assayed spectrophotometrically using $p$-nitroanilide substrates (Sigma): succinylalanylalanylprolylphenylalanyl $p$-nitroanilide and methoxysuccinylalanylalanylprolylvalyl $p$-nitroanilide for $\alpha$-CT and HLE, respectively. The reactions were performed in $0.025 \mathrm{M}$ sodium phosphate, $0.05 \mathrm{M} \mathrm{NaCl}$ at $\mathrm{pH} 7.5$ for $\alpha-\mathrm{CT}$ and $0.1 \mathrm{M}$ Hepes, $0.5 \mathrm{M} \mathrm{NaCl}, 0.01 \%$ (v/v) Tween 80 at $\mathrm{pH} 8.0$ for HLE. Assays contained $10 \%(\mathrm{v} / \mathrm{v}) \mathrm{DMSO}$ and were run at $25^{\circ} \mathrm{C}$ in a spectrophotometer Lambda 5 (Perkin-Elmer) or UVIKON 941 (Kontron), both equipped with a thermostatted cellholder.

$$
\mathrm{E}+\mathrm{I} \stackrel{K_{\mathrm{I}}}{\rightleftharpoons} \mathrm{E}^{*} \overbrace{k_{\mathrm{c}}}^{k_{\text {inact }}} \mathrm{E}+\mathrm{P} \text {-I } \quad \text { Inactivated enzyme }
$$

Suicide substrate inactivation can be represented by the minimum scheme above, $\mathrm{E}$ and $\mathrm{I}$ being the free forms of enzyme and inhibitor, $E^{*} I$ a kinetic chimere of the Michaelis complex and the acyl-enzyme, E-I the inactivated enzyme and $\mathrm{P}$ the product of hydrolysis of $\mathrm{I}$. The kinetic constants $k_{\text {inact }}$ and $K_{\mathrm{I}}$ were determined using the preincubation method or the progress curve method. ${ }^{38}$ Linear and non-linear regression fits of the experimental data to the equations were performed with Kaleidagraph version 3.0.1 (Abelbeck Software). At low inhibitor concentrations, the ratio $k_{\text {inact }} / K_{\mathrm{I}}$ was obtained as $k_{\text {obs }} /[\mathrm{I}]$. For the preincubation method, the enzyme and inhibitor concentrations were: $[\alpha-\mathrm{CT}]_{0}=7,12.5$ or $100 \mathrm{nM},[\mathrm{I}]_{0}=0.25-100 \mu \mathrm{M},[\mathrm{HLE}]_{0}=20 \mathrm{nM},[\mathrm{I}]_{0}=0.6-$ $20 \mu \mathrm{M}$. For the progress curve method, the experimental 
conditions were: $[\alpha-\mathrm{CT}]_{0}=12.5 \mathrm{nM},[\mathrm{S}]_{0}=100$ or $200 \mu \mathrm{M}$, $[\mathrm{I}]_{0}=0.01-10 \mu \mathrm{M}$.

The partition ratio $r=k_{\mathrm{c}} / k_{\text {inact }}$ which represents the average number of enzyme 'turnovers per inactivation' was obtained by plotting the residual activity at infinite time of an enzyme-inhibitor mixture versus the ratio $[\mathrm{I}]_{0} /[\mathrm{E}]_{0}$. The intercept of the linear plot obtained with the $x$ axis is equal to $r+1 .{ }^{39}$

Hydroxylamine reactivation assays were performed by treating inactivated $\alpha$-CT solutions with $0.5 \mathrm{M}$ hydroxylamine at $\mathrm{pH} 7.5$ and $25^{\circ} \mathrm{C}$ during $30 \mathrm{~min}$. Enzyme activity of aliquots was monitored and compared to a control.

In order to perform the amino acid analysis of native and inactivated $\alpha-\mathrm{CT}$ by $\mathbf{3 1}$ and $\mathbf{3 4}$, the enzyme samples were dried under vacuo and hydrolyzed by $6 \mathrm{~N} \mathrm{HCl}$ at $105^{\circ} \mathrm{C}$ during $23 \mathrm{~h}$. The amino acid mixtures were then modified using phenylisothiocyanate (PITC), analyzed by HPLC on a PICO-TAG column $(3.9 \times 150 \mathrm{~mm}$, WATERS) and compared to a sample of a standard amino acid mixture treated according to the same procedure. The determination of the amino acid composition was based on the presence of 4 tyrosine residues.

\section{X-Ray crystallography}

Crystals of 30, $\mathrm{C}_{17} \mathrm{H}_{10} \mathrm{O}_{4} \mathrm{BrCl}, \quad M_{r}=393.6$, were obtained by slow evaporation of a concentrated solution in $\mathrm{CH}_{3} \mathrm{CN}$. A crystal measuring $0.47 \times 0.28 \times$ $0.025 \mathrm{~mm}$ was selected for the crystallographic study: monoclinic, $\mathrm{P} 2{ }_{1}, a=6.248(1) \AA, b=7.618(1) \AA ⿻$ $15.975(2) \AA, \beta=94.87(1)^{\circ}, V=757.6(2) \AA,{ }^{3} Z=2, \mu=$ $5.488 \mathrm{~mm}^{-1}, D_{x}=1.725 \mathrm{~g} \mathrm{~cm}^{-3}, \lambda\left(\mathrm{Cu} K_{\alpha}\right)=1.54178 \AA$, $F(000)=392, \quad T=290 \quad \mathrm{~K}, 1893$ unique reflections $\left(R_{\text {int }}=0.015\right), \quad R_{1}=0.0338$ for $1798 \quad F_{\mathrm{o}}>4 \sigma\left(F_{\mathrm{o}}\right)$ and $w R_{2}=0.0947, \mathrm{GOF}=S=1.028$. Absorption effects were corrected using analytical methods, $T_{\max }=0.763$ and $T_{\min }=0.245$. Full matrix least-squares on $F^{2}$.

\section{Calculation}

All the calculations have been performed at the ab initio RHF level using the minimal basis set MINI-1' ${ }^{\prime}{ }^{40,41}$ They were performed with Gaussian $94^{42}$ on two computers, a Dec Alpha 8400 8-processor and a Dec Alpha 4100 4-processor running Digital Unix. The starting geometries were sketched drawn by standard fragments and then completely optimized following all the $3 \mathrm{~N}-6$ degrees of freedom either for the minima or the transition state structures. For each equilibrium structure, the thermochemistry data are derived from the analytical frequency calculation at $298.15 \mathrm{~K}$ and $1 \mathrm{~atm}$. The conformational analysis of $\mathbf{3 7}, \mathbf{3 8}$ and $\mathbf{3 9}$ has been performed following the rotatable bond of the carbonyl moiety of the substituent using a stepsize of 30 degrees. At each point, the $3 \mathrm{~N}-5$ degrees of freedom have been reoptimized allowing us to locate the positions of the extrema, i.e., the minima and the transition state structure(s) between them.

\section{Supporting information available}

X-Ray crystallographic data, including positional parameters, bond distances, bond angles, torsion angles, and anisotropic displacement parameter expressions for $\mathbf{3 0}$ and all the equilibrium structure geometries as well as frequency calculation and/or Z-matrices are available on request from the authors.

\section{Acknowledgements}

We thank C. Garreau for reactivation experiments. This work was supported in part by the grant no. 3.4570.99 of the National Fund for Scientific Research (FNRS, Belgium), from which B. Pirotte and G. Dive are Senior Research Associates. This work was supported in part by the Belgian Program on Interuniversity Poles of Attraction initiated by the Belgian State, Prime Minister's Office, Service fédéraux des affaires scientifiques, techniques et culturelles (PAI no P4/03), the Fonds de la Recherche Scientifique Médicale Belge (FRSM, grant no. 3.4531.92).

\section{References and Notes}

1. Powers, J. C.; Zimmerman, M. In Design of Enzyme Inhibitors as Drugs; Sandler, M., Smith, H. J., Eds.; Oxford University Press: Oxford, 1989; pp 596-619

2. Powers, J. C.; Harper, J. W. In Proteinase Inhibitors; Barett, A. J., Salvensen, G., Eds.; Elsevier: Amsterdam, 1986; pp 55-152.

3. Hlasta, D. J.; Pagani, E. D. Ann. Rep. Med. Chem. 1994, 29, 195.

4. Janoff, A. Am. Rev. Respir. Dis. 1985, 132, 417.

5. Demling, R. H. Annu. Rev. Med. 1995, 46, 193.

6. Janoff, A. Annu. Rev. Med. 1985, 36, 207.

7. Snider, G. L. Drug. Dev. Res. 1987, 10, 235.

8. Nadel, J. A. Am. Rev. Respir. Dis. 1991, 14, S48.

9. Rai, R.; Katzenellenbogen, J. A. J. Med. Chem. 1992, 35, 4297.

10. Rai, R.; Katzenellenbogen, J. A. J. Med. Chem. 1992, 35, 4150 .

11. Katzenellenbogen, J. A.; Rai, R.; Dai, W. Bioorg. Med. Chem. Lett. 1992, 2, 1399.

12. Alpegiani, M.; Bissolino, P.; Corigli, R.; Del-Nero, S.; Perrone, E.; Rizzo, V.; Sacchi, N.; Cassinelli, G.; Franceschi, G.; Baici, J. Med. Chem. 1994, 37, 4003

13. Finke, P. E.; Ashe, B. M.; Knight, W. B.; Maycock, A. L.; Navia, M. A.; Shah, S. K.; Thompson, K. R.; Underwood, D. J.; Weston, H.; Zimmerman, M.; Doherty, J. B. J. Med. Chem. 1990, 33, 2522 .

14. Finke, P. E.; Shah, S. K.; Fletcher, D. S.; Ashe, B. M.; Brause, K. A.; Chandler, G. O.; Dellea, P. S.; Hand, K. M.; Maycock, A. L.; Osinga, D. G.; Underwood, D. J.; Weston, H.; Davies, P. J. Med. Chem. 1995, 38, 2449.

15. Knight, W. B.; Green, B. G.; Chabin, R. M.; Gale, P.; Maycock, A. L.; Weston, H.; Kuo, D. W.; Westler, W. M.; Dorn, C. P.; Finke, P. E.; Hagmann, W. K.; Hale, J. J.; Liesh, J.; MacCoss, M.; Navia, M. A.; Shah, S. K.; Underwood, D.; Doherty, J. B. Biochemistry 1992, 31, 8160.

16. Wakselman, M.; Joyeau, R.; Kobaiter, R.; Bogetto, N.; Vergely, I.; Maillard, J.; Okochi, V.; Montagne, J. J.; ReboudRavaux, M. FEBS Lett. 1991, 282, 377. 
17. Groutas, W. C.; Houser-Archield, N.; Chong, L. S.; Venkataraman, R.; Epp, J. B.; Huang, H.; McClenahan, J. J. J. Med. Chem. 1993, 36, 3178 .

18. Desai, R. C.; Court, J. C.; Ferguson, E.; Gordon, R. J.; Hlasta, D. J.; Dunlap, R. P.; Franke, C. A. J. Med. Chem. 1995, 38, 1571.

19. Krantz, A.; Spencer, R. W.; Tam, T. F.; Liak, T. J.; Copp, L. J.; Thomas, E. M.; Rafferty, S. P. J. Med. Chem. 1990, 33, 464.

20. Uejima, Y.; Kokubo, M.; Oshida, J.; Kawabata, H.; Kato, Y.; Fujii, K. Pharmacol. Exp. Ther. 1993, 265, 516.

21. Hernandez, M. A.; Powers, J. C.; Glinski, J.; Oleksyszyn, J.; Vijayalakshmi, J.; Meyer, E. F., Jr. J. Med. Chem. 1992, 35, 1121 .

22. Kam, C. M.; Kerrigan, J. E.; Plaskon, R. R.; Duffy, E. J.; Lollar, P.; Suddath, F. L.; Powers, J. C. J. Med. Chem. 1994, 37, 1298 .

23. Kerrigan, J. E.; Oleksyszyn, J.; Kam, C. M.; Selzler, J.; Powers, J. C. J. Med. Chem. 1995, 38, 544.

24. Béchet, J.-J.; Dupaix, A.; Yon, J.; Wakselman, M.; Robert, J.-L.; Vilkas, M. Eur. J. Biochem. 1973, 35, 527.

25. Mor, A.; Maillard, J.; Favreau, C.; Reboud-Ravaux, M. Biochim. Biophys. Acta 1990, 1038, 119.

26. Groutas, W. C.; Kuang, R.; Venkataraman, R. Biochem. Biophys. Res. Commun. 1994, 198, 341.

27. Groutas, W. C.; Kuang, R.; Venkataraman, R.; Epp, J. B.; Ruan, S.; Prakash, O. Biochemistry 1997, 36, 4739.

28. Pochet, L.; Doucet, C.; Schynts, M.; Thierry, N.; Boggetto, N.; Pirotte, B.; Jiang, K.-Y.; Masereel, B.; de Tullio, P.; Delarge, J.; Reboud-Ravaux, M. J. Med. Chem. 1996, 39, 2579.

29. Wakselman, M. Nouv. J. Chim. 1983, 7, 439.

30. Dive, G.; Dehareng, D.; Peeters, D. Int. J. Quant. Chem. 1996, 58,85 .

31. Boggetto, N.; Vilain, A. C.; Montagne, J. J.; Reboud-
Ravaux, M.; Mazaleyrat, J. P.; Xie, J.; Wakselman, M. Bull. Soc. Chim. Fr. 1994, 131, 152.

32. Joyeau, R.; Felk, A.; Guilaume, S.; Wakselman, M.; Vergely, I.; Doucet, C.; Boggetto, N.; Reboud-Ravaux, M. J. Pharm. Pharmacol. 1996, 48, 1218.

33. Doucet, C.; Vergely, I.; Reboud-Ravaux, M.; Guilhem, J.; Kobaiter, R.; Joyeau, R.; Wakselman, M. Tetrahedron: Asymmetry 1997, 8, 739.

34. Doucet, C.; Pochet, L.; Thierry, N.; Pirotte, B.; Delarge, J.; Reboud-Ravaux, M. J. Med. Chem. 1999, 42, 4161.

35. $k_{\text {inact }} / K_{\mathrm{I}}$ for $\mathbf{5 2}, \mathbf{5 3}$ and $\mathbf{5 4}$ was 48,100, 762,700, $330 \mathrm{M}^{-1}$ $\mathrm{s}^{-1}$, respectively. See ref 28 .

36. Bowden, J.; Hanson, M. J.; Taylor, G. R. J. Chem. Soc. 1968, 174.

37. Lippold, B. C.; Garett, E. R. J. Pharm. Sci. 1971, 60, 1019. 38. Wakselman, M.; Xie, J.; Mazaleyrat, J.-P.; Bogetto, N.; Vilain, A.-C.; Montagne, J.-J.; Reboud-Ravaux, M. J. Med. Chem. 1993, 36, 1539.

39. Silverman, R. B. In Mechanism-Based Enzyme Inactivation: Chemistry and Enzymology; CRC Press: Boca Raton, FL, 1988; Vol. 1, pp 22-23.

40. Tatewaki, H.; Huzinaga, S. J. Comp. Chem. 1980, 1, 205.

41. Dive, G.; Dehareng, D.; Ghuysen, J. M. Theoret. Chim. Acta 1993, 85, 409.

42. Frisch, M. J.; Trucks, G. W.; Schlegel, H. B.;Gill, P. M. W.; Johnson, B. G.; Robb, M. A.; Cheeseman, J. R.; Keith, T.; Petersson, G. A.; Montgomery, J. A.; Raghavachari, K.; Al-Laham, M. A.; Zakrzewski, V. G.; Ortiz, J. V.; Foresman, J. B.; Cioslowski, J.; Stefanov, B. B.; Nanayakkara, A.; Challacombe, M.; Peng, C. Y.; Ayala, P. Y.; Chen, W.; Wong, M. W.; Andres, J. L.; Replogle, E. S.; Gomperts, R.; Martin, R. L.; Fox, D. J.; Binkley, J. S.; Defrees, D. J.; Baker, J.; Stewart, J. P.; Head-Gordon, M.; Gonzalez, C.; Pople, J. A. Gaussian 94, Revision D.4; Pittsburgh, PA, 1995. 